Article

\title{
Synthesis, Electrochemical and Spectroscopic Characterization of Selected Quinolinecarbaldehydes and Their Schiff Base Derivatives
}

\author{
Jakub Wantulok ${ }^{1}$, Marcin Szala ${ }^{2}\left(\mathbb{D}\right.$, Andrea Quinto ${ }^{3,4}$, Jacek E. Nycz ${ }^{1, *} \mathbb{(}$, \\ Stefania Giannarelli ${ }^{4}{ }^{\circ}$, Romana Sokolová ${ }^{3, *}{ }^{\mathbb{D}}$, Maria Książek ${ }^{5}$ and Joachim Kusz ${ }^{5}$ \\ 1 Institute of Chemistry, University of Silesia in Katowice, ul. Szkolna 9, PL-40007 Katowice, Poland; \\ jakub.wantulok1@gmail.com \\ 2 Institute of Polymer and Dye Technology, Lodz University of Technology, Stefanowskiego 12/16, \\ 90-924 Lodz, Poland; marcin.szala@p.lodz.pl \\ 3 J. Heyrovský Institute of Physical Chemistry of the Czech Academy of Sciences, Dolejškova 3, 18223 Prague, \\ Czech Republic; andrea.quinto28@libero.it \\ 4 Department of Chemistry and Industrial Chemistry, University of Pisa, Via Moruzzi 13, 56124 Pisa, Italy; \\ stefania.giannarelli@unipi.it \\ 5 Silesian Center for Education and Interdisciplinary Research, University of Silesia, Institute of Physics, \\ 75 Pułku Piechoty 1a, 41-500 Chorzów, Poland; maria.ksiazek@us.edu.pl (M.K.); \\ joachim.kusz@us.edu.pl (J.K.) \\ * Correspondence: jacek.nycz@us.edu.pl (J.E.N.); sokolova@jh-inst.cas.cz (R.S.); \\ Tel.: +48-32-359-1446 (J.E.N.); +420-26605-3525 (R.S.)
}

Academic Editors: Sven Mangelinckx and Jacek Nycz

Received: 7 April 2020; Accepted: 26 April 2020; Published: 28 April 2020

\begin{abstract}
A new approach to the synthesis of selected quinolinecarbaldehydes with carbonyl groups located at $\mathrm{C} 5$ and/or in C7 positions is presented in this paper in conjunction with spectroscopic characterization of the products. The classical Reimer-Tiemann, Vilsmeier-Haack and Duff aldehyde synthesis methods were compared due to their importance. Computational studies were carried out to explain the preferred selectivity of the presented formylation transformations. A carbene insertion reaction based on Reimer-Tiemann methodology is presented for making 7-bromo-8-hydroxyquinoline-5-carbaldehyde. Additionally, Duff and Vilsmeier-Haack reactions were used in the double formylation of quinoline derivatives and their analogues benzo[ $h]$ quinolin-10-ol, 8-hydroxy-2-methylquinoline-5,7-dicarbaldehyde, 8-(dimethylamino) quinoline-5,7-dicarbaldehyde and 10-hydroxybenzo[h]quinoline-7,9-dicarbaldehyde. Four Schiff base derivatives of 2,6diisopropylbenzenamine were prepared from selected quinoline-5-carbaldehydes and quinoline-7carbaldehyde by an efficient synthesis protocol. Their properties have been characterized by a combination of several techniques: MS, HRMS, GC-MS, FTIR, electronic absorption spectroscopy and multinuclear NMR. The electrochemical properties of 8-hydroxy-quinoline-5-carbaldehyde, 6-(dimethylamino)quinoline-5-carbaldehyde and its methylated derivative were investigated, and a strong correlation between the chemical structure and obtained reduction and oxidation potentials was found. The presence of a methyl group facilitates oxidation. In contrast, the reduction potential of methylated compounds was more negative comparing to non-methylated structure. Calculations of frontier molecular orbitals supported the finding. The structures of 8-hydroxy-2-methylquinoline-5,7-dicarbaldehyde and four Schiff bases were determined by single-crystal X-ray diffraction measurements.
\end{abstract}

Keywords: vilsmeier-haack; reimer-tiemann; duff; aldehyde; aldazine; heterocyclic; cyclic voltammetry 


\section{Introduction}

Aldehydes are a class of compounds of great interest from the synthetic, theoretical and application point of view, which can be transformed into a wide range of structural frameworks through application of a variety of reactions. Various synthetic protocols have been developed including the classical Reimer-Tiemann, Vilsmeier-Haack and Duff reactions, which are well known as versatile synthetic tools for the formylation of electron-rich aromatics. However, literature data has often inaccurately reported the position of the newly formed carbonyl group(s). Formylation of 8-hydroxyquinoline under Reimer-Tiemann condition can go to both the C5 (38\%) and C7 (10\%) positions [1]. On the other hand González-Vera et al. reported the formylation of 2-methylquinolin-8-ol leading exclusively to 8-hydroxy-2-methylquinoline-5-carbaldehyde in 64\% yield [2] similarly to Chen et al. who formylated 8-hydroxyquinoline and obtained 8-hydroxyquinoline-5-carbaldehyde in 19.3\% yield [3]. Ding. et al. only obtained 8-hydroxy-7-quinaldinecarbaldehyde, a product formylated in a different position [4]. In this study we propose the transformation of some newly formed aldehydes into sterically hindered crystalline Schiff bases.

\section{Results and Discussion}

In the current study, the formylation reactions of selected quinoline derivatives at $\mathbf{R}, \mathbf{R}^{\mathbf{1}}$ and $\mathbf{R}^{\mathbf{2}}$ positions were the focus. These type compounds have not been fully exploited and may be served as interesting building blocks for synthetic purposes.

\subsection{Synthesis and Structural Characterization}

The synthesis of certain quinolinecarbaldehydes 2 were based on closely related Reimer-Tiemann (R-T), Vilsmeier-Haack (V-H) and Duff (D) formylation reactions (Scheme 1).

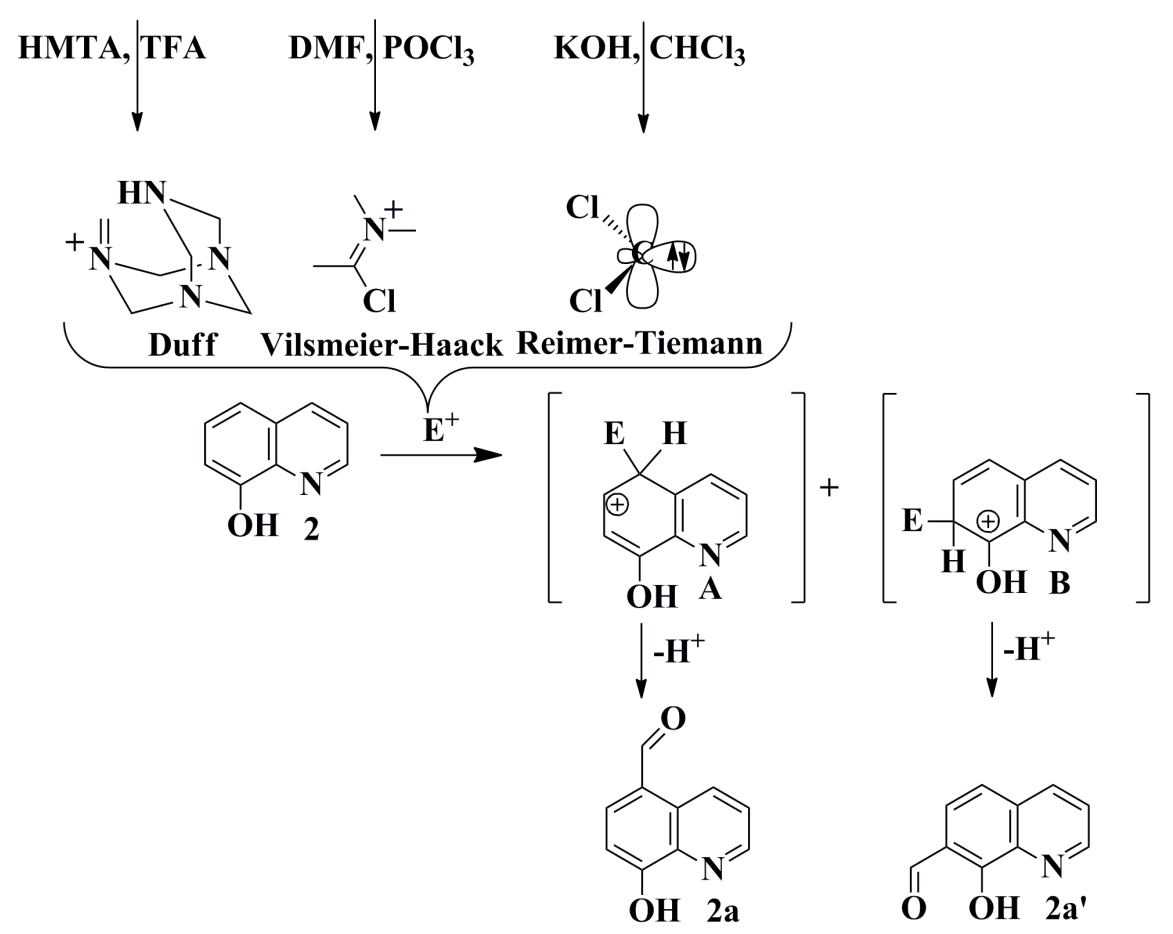

Scheme 1. Formylation of 8-hydroxyquinoline (1c).

The aim of the current study is to explore selected synthetic routes, and formylated a series of derivatives of 8-hydroxyquinoline have been prepared as shown in Schemes 2 and 3. 


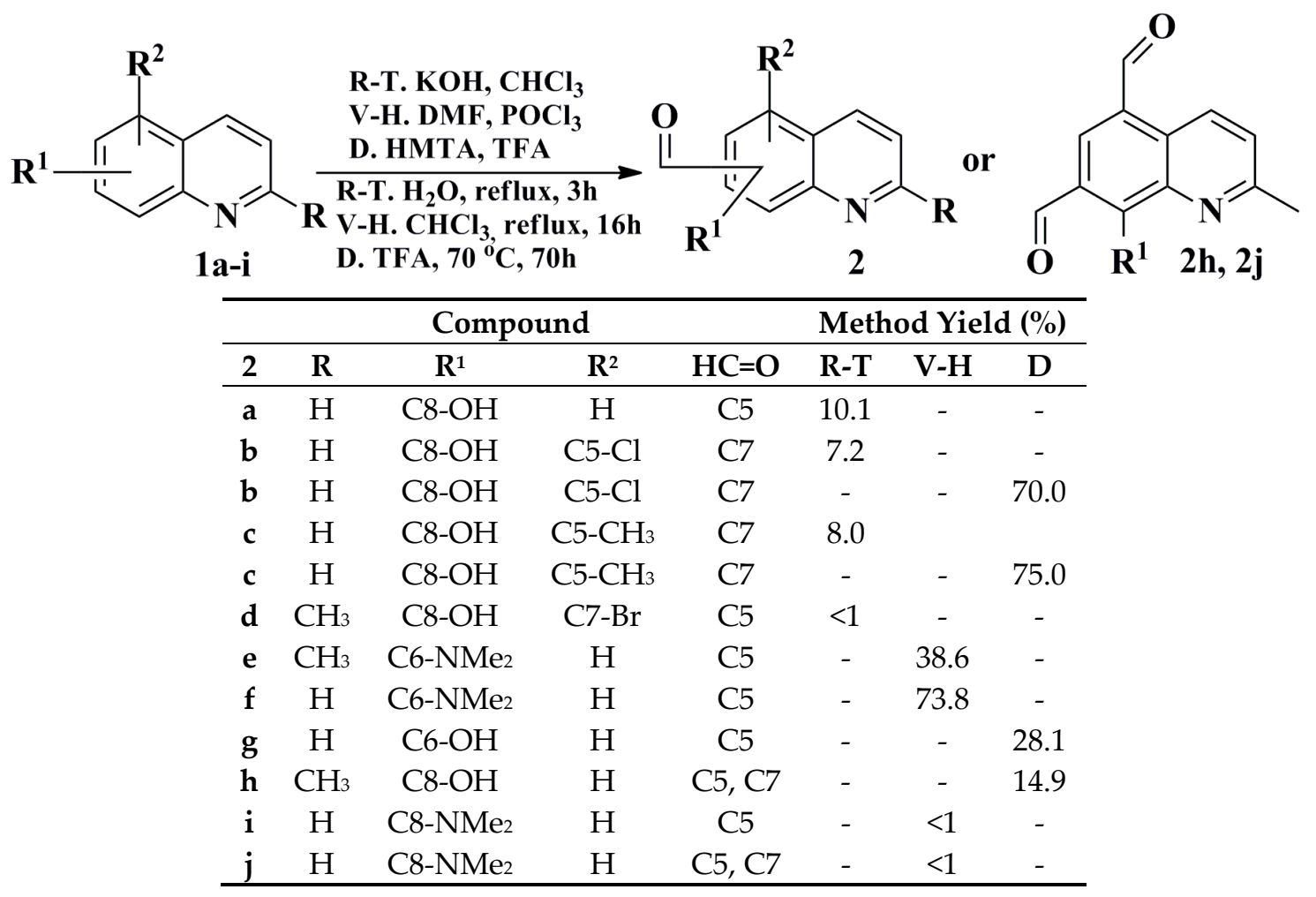

Scheme 2. Synthesis of quinolinecarbaldehydes 2 .

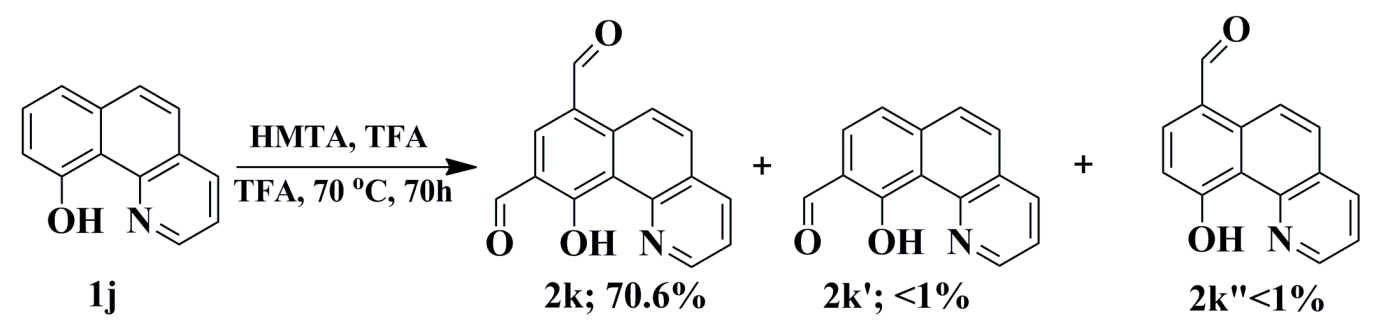

Scheme 3. Duff type formylation of benzo[h]quinolin-10-ol (1j).

A lone pair of electrons on the hydroxyl oxygen or dimethylamino nitrogen at $\mathbf{R}^{1}$ position on phenyl ring are conjugated with the $\pi$ system of quinolone, which increases the electron density at both the $\mathrm{C} 5$ and $\mathrm{C} 7$ positions on the phenyl ring in all studied quinolines [5,6]. Both positions are suitable for substitution reaction via a $S_{E} A r$ mechanism [6]. The formulation mechanisms of Reimer-Tiemann, Vilsmeier-Haack and Duff reactions are similar to each other and to other electrophilic aromatic substitution reactions. However the initial electrophile reactions are different among these methods. In the case of the Reimer-Tiemann reaction, it is in situ Fisher type electrophilic carbene generated (in most cases dichlorocarbene), for Vilsmeier-Haack it is Vilsmeier's reagent, and for Duff reaction it has been proposed an initial aminoalkylation followed by dehydrogenation (generated from HMTA) [7] (Scheme 1). It is important to notice that all these electophiles possess different electrophilicity. The attack by an electrophile generates a Wheland intermediate cation (or arenium ion) followed by the loss of a proton to restore the aromaticity (Scheme 1). Analogically to our recent results [6] the substitution at C5 $\left(\mathbf{R}^{2}\right)$ position would have a great stabilizing effect on the adjacent carbon than at C7 $\left(\mathbf{R}^{\mathbf{1}}\right)$ position in quinoline constitution (Scheme 2). Several authors announced the similar structure of 8-hydroxyquinoline with newly formed group at C5 position on phenol ring in the same type of reactions.

The Vilsmeier's reagent and electrophilic dichlorocarbene possess electron-withdrawing (EW) ability. One consequence of the existence of EW groups in electrophiles is a decreased electron 
density in the newly generated Wheland cations (Scheme 1), which deactivate the $N, N$-dimethylaniline (or phenol) ring for the next substitution. A dimethylamino moiety, like a hydroxyl group in the C8 position, increases the electron density at both the $\mathrm{C} 5$ and $\mathrm{C} 7$ sites, which makes double formylation leading to 8-(dimethylamino)quinoline-5,7-dicarbaldehyde ( $2 \mathbf{j}$, yield $<1 \%$ ) possible in the case of the Vilsmeier-Haack transformation (Figure 1). In contrast the Duff cyclic electrophile, after the generation of a Wheland cation (Scheme 1), does not deactivate the phenol ring for the next substitution, which allows the double formylation to generate 8-hydroxy-2-methylquinoline-5,7-dicarbaldehyde (2h) and 10-hydroxybenzo[h]quinoline-7,9-dicarbaldehyde (2j) in good yields. Zhang et al. have claimed an $82 \%$ isolated yield of 8-hydroxyquinoline-5,7-dicarbaldehyde in a similar procedure [8]. The absence of a methyl group in the $\mathrm{C} 2(\mathbf{R})$ position could have a positive influence to increase the yield of products. $\mathbf{R}$ substituents can undergo further side reactions. Additionally, in both reaction mixtures we identified monoformylated products. It is, at first sight, somewhat surprising that the formylation of 6-hydroxyquinoline (1h) using the Duff method led exclusively to a monoaldehyde with the newly formed carbonyl group in the C5 position (Scheme 2) [9]. The differences in reactivity between 8-hydroxyquinoline (1c), 6-hydroxyquinoline (1h), N,N-dimethylquinolin-6-amine (1e) and $\mathrm{N}, \mathrm{N}$-dimethylquinolin-8-amine (1i) could be explained by the differences in electrostatic potentials of the atoms participating in the formylation transformation (Figure 1). The formal charge of atoms in the $\mathrm{C} 5-\mathrm{H}$ and $\mathrm{C} 7-\mathrm{H}$ bonds were calculated based on electrostatic potentials, which are given in units of electrons and are shown in Figure 1. A positive charge indicates a deficiency of electrons on an atom and a negative charge, an excess of electrons. The electrostatic potential for a hydrogen atom is marked in gray (positive value) and for carbon in black (negative value). The differences in their potential are marked in blue. The higher difference in atomic charges between $\mathrm{C} 5$ and $\mathrm{C} 7$ positions show the preference of selected monoformylations products with novel carbonyl group only in C5 position. The difference of electrostatic potential of $\mathrm{C} 5-\mathrm{H}$ bond 0.556 for $1 \mathrm{e}$ suggests the easier cleavage of $\mathrm{H}$ atom from $\mathrm{C} 5$, compared to $\mathrm{C} 7-\mathrm{H}$ with electrostatic potential difference 0.318 (for $\mathbf{1 h}$, similarly). The smaller differences in the atomic charges difference of atoms in bonds $\mathrm{C} 5-\mathrm{H}$ and $\mathrm{C} 7-\mathrm{H}$ suggest the possibility of double formylation and the presence of both regioisomers with new carbonyl group in C5 and C7 positions (Figure 1).
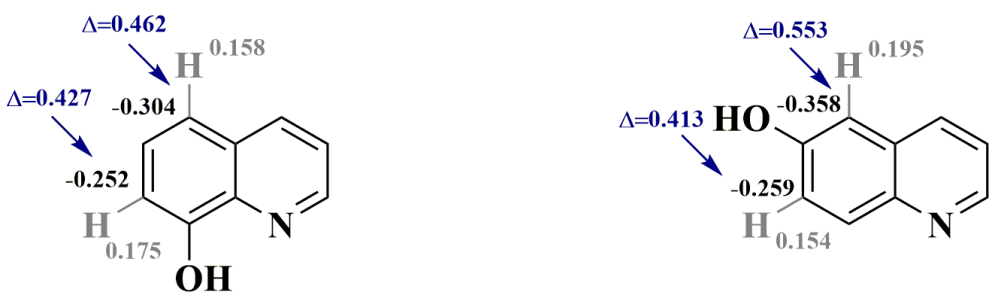

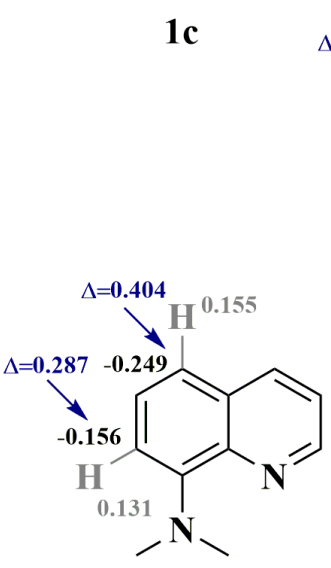

$1 \mathbf{i}$

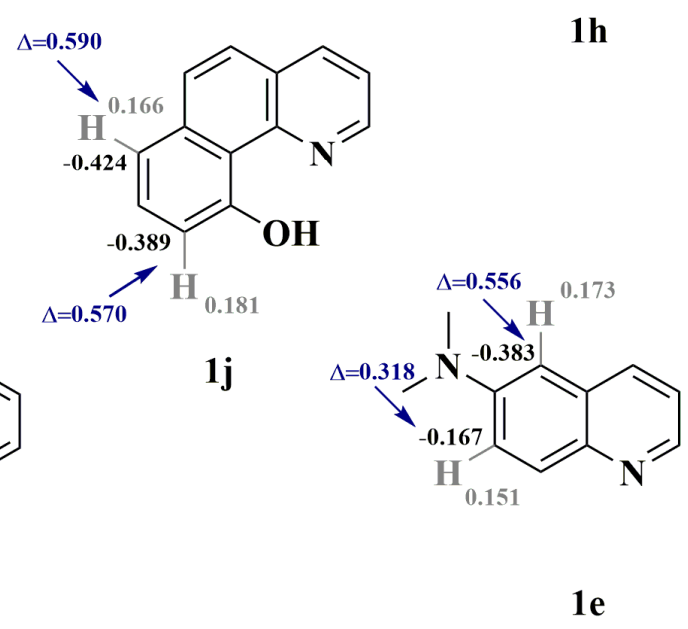

Figure 1. The electrostatic potentials for the selected quinolines. 
The two transition states presented in Scheme 1 would be similar in terms of structure between intermediate $\mathbf{A}$ and $\mathbf{B}$. If we accept Scheme 1 as a model for the formylation, a substitution at the C5 position would have a greater stabilizing effect on the adjacent carbon than that at the C7 position in the quinoline scaffold. This discrepancy between the electron density and preferred position of substitution was explained by Olah, as the weaker electrophiles (or with less nucleophilicity of aromatics) showed higher substrate selectivity. The transition states are of a "late" nature resembling the intermediates and the ortho/para ratio decreases, with para-substitution becoming predominant [10]. Formylation of 2-methylquinolin-8-ol (1b) and 8-hydroxyquinoline (1c) in all the presented methodologies led to complicated reaction mixtures. However, it was noticed that dialdehydes $\mathbf{2 h}$ and $\mathbf{2 k}$ were easy to isolate because of their low solubility in most solvents. In this case isolation relies on filtration, followed by washing with chloroform and methanol. In the reaction mixtures of the Reimer-Tiemann and Vilsmeier-Haack transformations the presence of two possible regioisomers with newly formed carbonyl groups at the C5 and C7 positions was detected by ${ }^{1} \mathrm{H}-\mathrm{NMR}$ and GC-MS techniques for the first time (Schemes 1 and 2, Figure S1e in the Supplementary Data). For the Reimer-Tiemann reaction both regioisomers were obtained in a 35:28 ratio (2a:2a') (Figure S1e). These regioisomers with $\operatorname{tr}_{\mathrm{C} 5-\mathrm{C}=\mathrm{O}}=6.024 \mathrm{~min}$. and $\operatorname{tr}_{\mathrm{C} 7-\mathrm{C}=\mathrm{O}}=6.360 \mathrm{~min}$. possess similar mass spectral patterns, and the same $m / z$ (Figure S1c,d, Supplementary Data) and display characteristic $m / z=173 \mathrm{M}^{+}$molecular ions, and $m / z=144$ and 116 fragment ions. All the presented quinolinecarbaldehydes 2 show a preferential fragmentation with the initial loss of a carbonyl group, followed by the loss of $\mathrm{C}=\mathrm{O}$ of the phenolic ring and further decomposition (Supplementary Data).

The ${ }^{1} \mathrm{H}-\mathrm{NMR}$ spectra of molecules 2 showed distinctive $\mathrm{H}-1$ signals from the $\mathrm{HC}=\mathrm{O}$ proton of carbonyl group located at the $\mathrm{C} 5$ and $\mathrm{C} 7$ positions (or C7 and C9 in the case of heterocycle 2k) with chemical shifts of ca. 10.1 and 10.5 ppm, respectively. The analysis of the trends in ${ }^{1} \mathrm{H}-\mathrm{NMR}$ chemical shifts revealed that the presence of intramolecular hydrogen bonds between neighboring carbonyl group located at C7 position and hydroxyl or dimethylamino group at C8 position increased the deshielding effect, resulting in the low-field signals. The chemical shifts in DMSO solution were moved to downfield (larger $\delta ; 10.5 \mathrm{ppm})$, while the higher field signal (10.1 ppm) is for a carbonyl group located at $\mathrm{C} 5$ position, where intramolecular hydrogen bonds were absent. In contrast, the proton of $\mathrm{HC}=\mathrm{N}$ group for molecules 3 (Scheme 5) are located at C5 (8.51 ppm) and C7 (8.38 ppm). The ${ }^{13} \mathrm{C}-\mathrm{NMR}$ spectra showed an opposite effect to the ${ }^{1} \mathrm{H}-\mathrm{NMR}$ ones. The carbon atoms of the carbonyl groups located at the C5 and C7 positions showed distinctive signals with ${ }^{13} \mathrm{C}$ chemical shifts of ca. 192 and 188 ppm, respectively. The chemical shifts were moved to downfield (larger $\delta$ ) for a non-protonated carbonyl group at the C5 position with resonance signals at ca. $192 \mathrm{ppm}$. The deprotonation of the carbonyl group makes the carbon atom more positive, which moves the chemical shift downfield (larger $\delta$ ). In the constitution of molecules 3 (Scheme 5), the carbon atoms of the HC=N group located at C5 (163 ppm) and C7 (165 ppm) positions showed opposite effects, which can be explained in the frame of electron density.

The IR spectra of molecules 2 showed distinctive carbonyl signals for the groups located at C5 and C7 [or C7 and C9 in the case of heterocycle $\mathbf{2 k}$ ] positions in the range 1663-1686 $v C=O$. The analysis of the trends suggests that carbonyl group located at C5 possess rather smaller values than that at C7. In the case of $\mathbf{2} \mathbf{j}$, for the first time we were able to detect two signals from both carbonyl groups located at C5 and C7 (Figure 2).

Comparison of the double formylated products $2 \mathbf{h}$ and $2 \mathbf{j}$ revealed that the presence of intramolecular and intermolecular hydrogen bonds between the carbonyls and hydroxyl groups has the impact on overlapping signals (Figure 2). This could explain why compound $\mathbf{2} \mathbf{j}$ possesses a dimethylamino group at the $\mathrm{C} 8$ position instead of a hydroxyl group and has two separate signals at $1678 v_{\mathrm{C}=\mathrm{O}}$ and $1661 v_{\mathrm{C}=\mathrm{O}}$. 

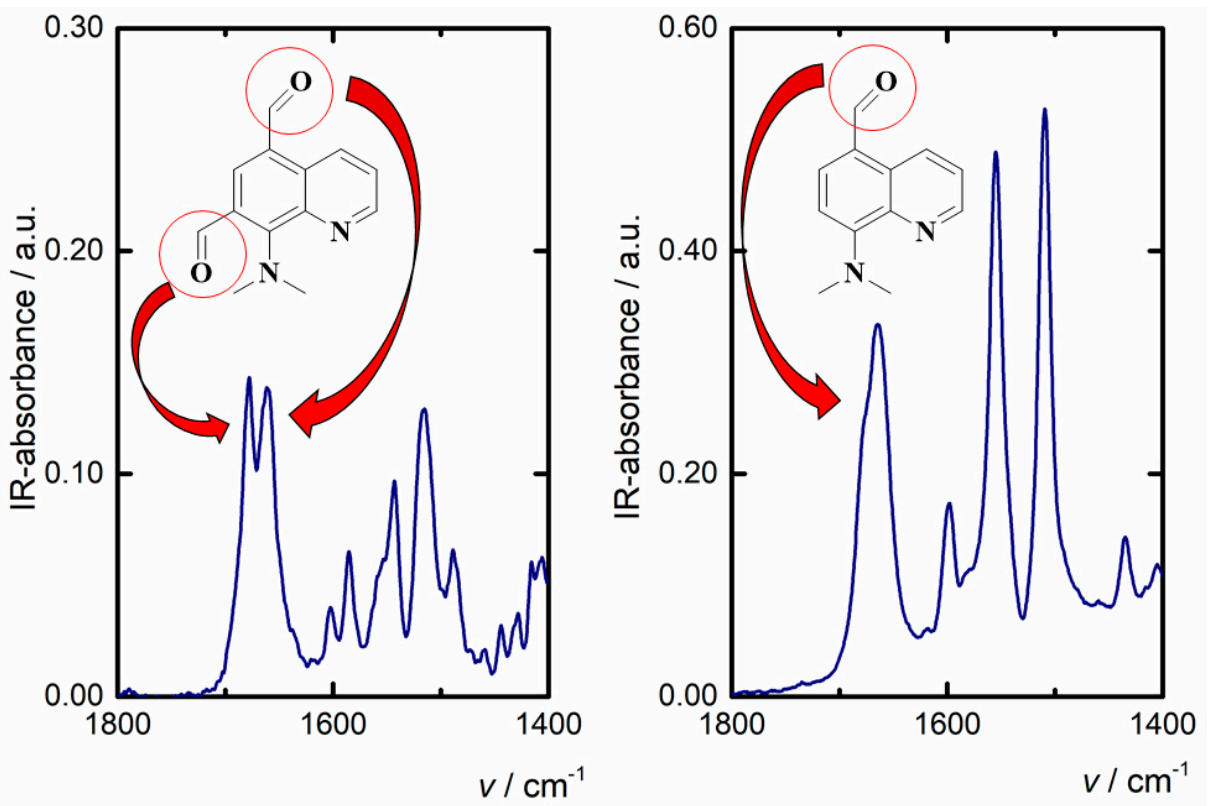

Figure 2. IR spectra of $2 \mathbf{j}$ (left) and $2 \mathbf{i}$ (right).

Comparing the yields of heterocycles 2 presented in Scheme 2, the Duff methodology appeared superior to the Reimer-Tiemann and Vilsmeier-Haack reactions for formylation of phenol derivatives, and gave a lower yield for $\mathrm{N}, \mathrm{N}$-dimethylaniline derivatives. More attention has been paid to the Reimer-Tiemann reaction and the generation of Fisher type electrophilic carbenes to show its potentially rich chemistry. One of the characteristic reactions of the carbene moiety is insertion reactions. DeAngelis et al. reacted an initially generated dichlorocarbene with indoles to form a ring expansion or a dichloromethyl-substituted product [11]. We applied the Reimer-Tiemann methodology the first time to show carbene insertion into a C-Br bond to produce 7-bromo-8-hydroxyquinoline-5-carbaldehyde (2d). Under standard Reimer-Tiemann conditions, molecule 1a and other reagents were irradiated by a $75 \mathrm{~W}$ lamp to initiate the reactions in the presence of carbenes. Although relatively higher yields was observed during irradiation, unfortunately, the yield of this preliminary reaction is not satisfactory yet (Scheme 1).

The Reimer-Tiemann and Vilsmeier-Haack reactions occur at a basic environment in contrast to the Duff protocol which occurs in an acidic medium. A negative impact on the synthesis of quinolinecarbaldehydes 2 was noticed during final stage when a basic environment was applied in hydrolysis reactions. This is not surprising, because aromatic aldehydes can disproportionate in strongly basic solutions according to well-known Cannizzaro reaction mechanism, especially during long time exposure. To avoid this possible reactivity in a basic environment the reaction time was reduced to three hours for the Reimer-Tiemann protocol. The next limitation or potentially a further development for both Reimer-Tiemann and Vilsmeier-Haack reactivity could be linked to the presence of a methyl group at the $\mathbf{R}$ position in the quinoline skeleton. The newly formed aldehydes can be reacted under base-catalyzed condensation reactions, such as the Perkin transformation, leading to styryl type compounds. Like Nandhakumar et al. we isolated the product from the reaction between the electrophilic Vilsmeier's reagent generated in situ and the methyl group located at the $\mathbf{R}$ position in the quinoline ring [12]. After hydrolysis a moderate yield of (Z)-8-hydroxy-2-(2-hydroxyvinyl)quinoline-5-carbaldehyde (2l) was isolated (Scheme 4). This product adopts a $Z$ conformation due to the presence of a pseudo-ring which is stabilized by intramolecular hydrogen bonding (Scheme 4 ). The small $J_{\mathrm{H}, \mathrm{H}}$ coupling constants proved the presence of $Z$ conformer over $E$, due to the Karplus equation. The molecule $\mathbf{2 1}$ is similarly to other quinolinecarbaldehydes 2 which had preferential fragmentation with the initial loss of carbonyl group (Figure S6d). 


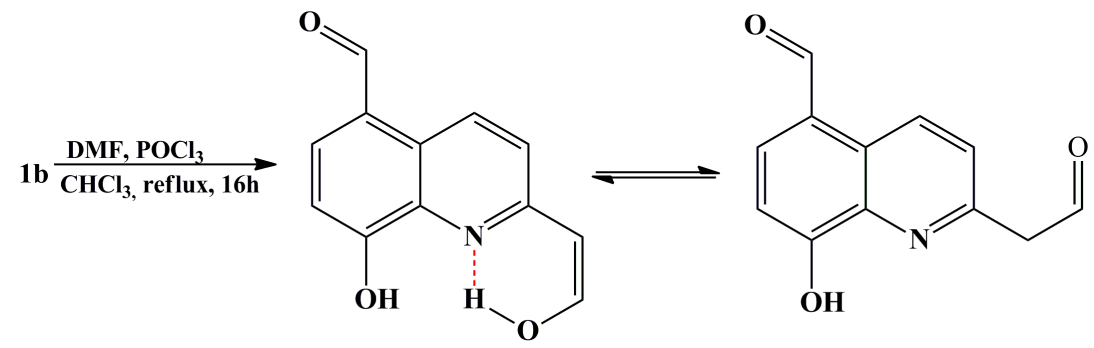

Scheme 4. Synthesis of (Z)-8-hydroxy-2-(2-hydroxyvinyl)quinoline-5-carbaldehyde (21). Intramolecular hydrogen-bonding interactions influencing the conformation of molecule $\mathbf{2 l}$.

As presented above, the reactivity between the electrophilic Vilsmeier's reagent and the methyl group located at the $\mathrm{C} 2$ position in the quinoline moiety could be explained by the electron density at the $\mathrm{C} 2(-0.714 \mathbf{1 b})$ position. It is important to pay attention to the hazards of the Vilsmeier-Haack reaction due to its thermal instability of the Vilsmeier intermediate, especially for multigram scale reactions [13]. A further limitation of the Vilsmeier-Haack reaction was described by Morimura et al. Derivatives of 8-hydroxyquinoline like other phenol-type reagents possess hydroxyl nucleophilic substituents that can react with $\mathrm{POCl}_{3}$ and the Vilsmeier's reagent leading to aryl formates [14].

The Duff reaction occurring in acidic environments also has some limitations. The low yield obtained in the formylation of amine derivatives is a result of the acidic environment used during the procedure. The nitrogen atoms of molecule 1e are protonated in an acidic environment and consequently form a dimethylaminium group in situ at the $\mathrm{C} 6$ position which does not activate the benzene ring to facilitate aromatic electrophilic substitution, and consequently does not undergo the Duff reaction. In this case the starting material was recovered (Scheme 1).

Some selected quinolinecarbaldehydes 2 were reacted with 2,6-diisopropylbenzenamine as an example of a primary amine giving four crystalline Schiff bases with yields up to $80 \%$ (Scheme 5). The addition of a 2,6-diisopropylbenzenamine nucleophile to heterocycles $\mathbf{2 a}, \mathbf{2 c}, \mathbf{2 e}$ or $\mathbf{2 f}$ is a nucleophilic addition-elimination reaction. The final products are an imine-Schiff base and water. As a reversible reaction, in acidic aqueous solutions, the products are hydrolyzed back to the aldehydes and amine. The equilibrium favors the nitrogen-protonated tetrahedral intermediate because nitrogen is more basic than oxygen. The equilibrium can be forced toward the imine species by removing water as it is formed. $\mathrm{MgSO}_{4}$ was used as dehydrating agent. The choice of 2,6-diisopropylbenzenamine is because it easily forms high quality crystals [15].

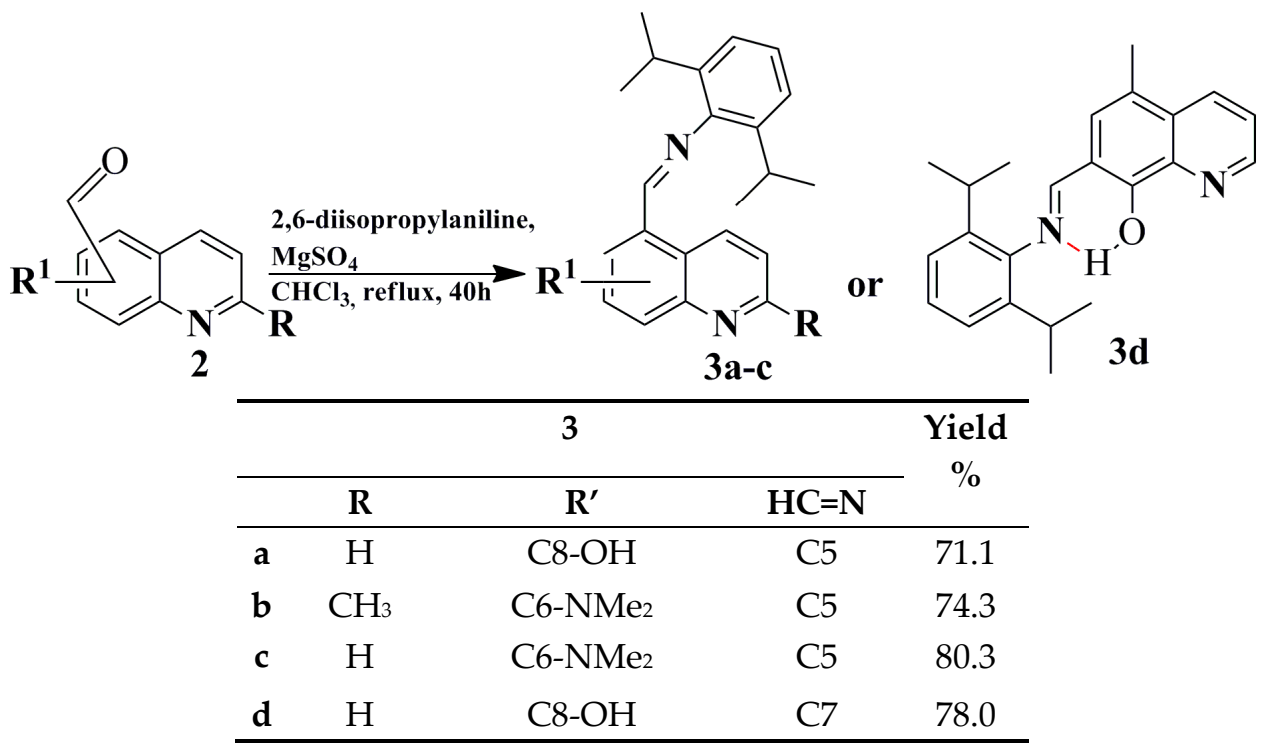

Scheme 5. Synthesis of Schiff bases 3. $\mathrm{R}=\mathrm{H}, \mathrm{CH}_{3}, \mathrm{R}^{\prime}=\mathrm{Me}, \mathrm{C} 8-\mathrm{OH}, \mathrm{C} 6-\mathrm{NMe}_{2}$. 


\subsection{Crystal Structure Determination and Refinement}

Data for the molecules $\mathbf{2 h}, \mathbf{3 a}, \mathbf{3 b}$ and $\mathbf{3 d}$ were collected on a SuperNova diffractometer using an Atlas CCD detector, while the measurement of compound $3 \mathrm{c}$ was performed on an Xcalibur diffractometer with a Sapphire 3 CCD detector. Graphite-monochromated Mo- $\mathrm{K}_{\alpha}$ radiation was used for all measurements. The crystals of compounds $\mathbf{2 h}, \mathbf{3 a}, \mathbf{3 b}$ and $\mathbf{3 d}$ were cooled down by a cold dry nitrogen gas stream (Oxford Cryosystems equipment), while the crystal of compound $3 \mathrm{c}$ was measured at room temperature. The temperature stability was $\pm 1 \mathrm{~K}$. The structures were solved by direct methods using SHELXS-2013 program and refined by full-matrix least-squares on $\mathrm{F}^{2}$ (all data) using the SHELXL-2014/7 program [16]. All non-hydrogen atoms were refined anisotropically. All H atoms bound to $\mathrm{C}$ atoms were refined using a riding model with $\mathrm{C}-\mathrm{H}$ distances of $0.95 \AA$ (aromatic), $0.98 \AA$ (methyl) or $1 \AA$ (methine) and Uiso(H) values of $1.2 \mathrm{Ueq}(\mathrm{C})$ or $1.5 \mathrm{Ueq}(\mathrm{C})$. Hydroxyl $\mathrm{H}$ atoms were refined with distances of $0.84 \AA$ and $\operatorname{Uiso}(\mathrm{H})$ values of $1.5 \mathrm{Ueq}(\mathrm{O})$. Details concerning crystal data and refinement are gathered in Tables 1 and 2.

Table 1. Crystal data and structure refinement details of compounds $2 \mathrm{~h}, 3 \mathbf{a}, 3 \mathbf{b}, 3 \mathbf{c}$ and $3 \mathrm{~d}$.

\begin{tabular}{|c|c|c|c|c|c|}
\hline & $2 \mathrm{~h}$ & $3 \mathbf{a}$ & $3 b$ & $3 c$ & $3 d$ \\
\hline Empirical formula & $\mathrm{C}_{12} \mathrm{H}_{9} \mathrm{NO}_{3}, \mathrm{CHCl}_{3}$ & $3\left(\mathrm{C}_{22} \mathrm{H}_{24} \mathrm{~N}_{2} \mathrm{O}\right) \cdot \mathrm{CH}_{3} \mathrm{CN}$ & $\mathrm{C}_{25} \mathrm{H}_{31} \mathrm{~N}_{3}$ & $\mathrm{C}_{24} \mathrm{H}_{29} \mathrm{~N}_{3}$ & $\mathrm{C}_{23} \mathrm{H}_{26} \mathrm{~N}_{2} \mathrm{O}$ \\
\hline Temperature (K) & $100(1)$ & $100(1)$ & $100(1)$ & 293(1) & $80(1)$ \\
\hline Wavelength $(\AA)$ & & \multicolumn{4}{|c|}{$0.71073(\mathrm{Mo} \mathrm{K} \alpha)$} \\
\hline Crystal system & Orthorhombic & Trigonal & Orthorhombic & Monoclinic & Monoclinic \\
\hline Space group & Pnma & $P 3_{1} \mathrm{c}$ & Pbca & $P 2_{1} / \mathrm{c}$ & $P 2_{1} / \mathrm{c}$ \\
\hline \multicolumn{6}{|l|}{ Unit cell dimensions } \\
\hline $\mathrm{a}(\AA)$ & $26.1040(14)$ & $29.4970(4)$ & $18.8459(8)$ & $9.0651(3)$ & $24.0519(9)$ \\
\hline $\mathrm{b}(\AA)$ & $6.4668(4)$ & $29.4970(4)$ & $11.0427(3)$ & $11.2850(3)$ & $16.2882(7)$ \\
\hline$c(\AA)$ & $8.2056(4)$ & $12.0258(3)$ & $20.8067(6)$ & $20.8767(7)$ & $9.7079(3)$ \\
\hline$\alpha(0)$ & 90 & 90 & 90 & 90 & 90 \\
\hline$\beta(0)$ & 90 & 90 & 90 & $93.873(3)$ & $99.189(3)$ \\
\hline$\gamma(\mathrm{o})$ & 90 & 120 & 90 & 90 & 90 \\
\hline Volume $\left(\AA^{3}\right)$ & $1385.18(13)$ & $9061.5(3)$ & $4330.1(3)$ & $2130.80(12)$ & $3754.4(2)$ \\
\hline $\mathrm{Z}$ & 4 & 6 & 8 & 4 & 8 \\
\hline $\begin{array}{l}\text { Calculated density } \\
\qquad\left(\mathrm{Mg} / \mathrm{m}^{3}\right)\end{array}$ & 1.604 & 1.142 & 1.146 & 1.121 & 1.226 \\
\hline $\begin{array}{c}\text { Absorption } \\
\text { coefficient }\left(\mathrm{mm}^{-1}\right)\end{array}$ & 0.666 & 0.070 & 0.068 & 0.066 & 0.075 \\
\hline $\mathrm{F}(000)$ & 680 & 3336 & 1616 & 776 & 1488 \\
\hline $\begin{array}{l}\text { Crystal dimensions } \\
\qquad(\mathrm{mm})\end{array}$ & $0.12 \times 0.10 \times 0.02$ & $0.18 \times 0.13 \times 0.03$ & $0.25 \times 0.02 \times 0.02$ & $0.56 \times 0.22 \times 0.09$ & $0.30 \times 0.05 \times 0.02$ \\
\hline $\begin{array}{l}\theta \text { range for data } \\
\text { collection }\left(^{\circ}\right)\end{array}$ & 2.932 to 26.371 & 2.875 to 24.710 & 3.452 to 26.370 & 3.401 to 26.367 & 3.033 to 26.371 \\
\hline Index ranges & $\begin{array}{c}-32 \leq h \leq 32 \\
-6 \leq k \leq 8 \\
-10 \leq l \leq 10\end{array}$ & $\begin{array}{l}-34 \leq h \leq 34 \\
-34 \leq k \leq 31 \\
-14 \leq l \leq 14\end{array}$ & $\begin{array}{l}-21 \leq h \leq 23 \\
-13 \leq k \leq 9 \\
-26 \leq l \leq 26\end{array}$ & $\begin{array}{l}-11 \leq h \leq 11 \\
-14 \leq k \leq 9 \\
-26 \leq l \leq 26\end{array}$ & $\begin{array}{c}-30 \leq h \leq 30 \\
-20 \leq k \leq 20 \\
-9 \leq l \leq 12\end{array}$ \\
\hline Reflections collected & 13863 & 69751 & 25986 & 25693 & 30149 \\
\hline $\begin{array}{l}\text { Independent } \\
\text { reflections }\end{array}$ & $1543[\mathrm{R}(\mathrm{int})=0.0162]$ & $10284[\mathrm{R}(\mathrm{int})=0.0713]$ & $4420[\mathrm{R}(\mathrm{int})=0.0680]$ & $4343[\mathrm{R}(\mathrm{int})=0.0509]$ & $7669[\mathrm{R}(\mathrm{int})=0.0599]$ \\
\hline $\begin{array}{l}\text { Data/restraints/ } \\
\text { parameters }\end{array}$ & $1543 / 0 / 120$ & $10284 / 1 / 721$ & $4420 / 0 / 260$ & $4343 / 0 / 251$ & $7669 / 0 / 493$ \\
\hline Goodness-of-fit on $\mathrm{F}^{2}$ & 1.223 & 1.070 & 1.072 & 1.026 & 1.032 \\
\hline $\begin{array}{l}\text { Final } R \text { indices } \\
\quad(I>2 \sigma(I))\end{array}$ & $\begin{array}{c}\mathrm{R}_{1}=0.0547 \\
\mathrm{wR}_{2}=0.1379\end{array}$ & $\begin{array}{r}\mathrm{R}_{1}=0.0581 \\
\mathrm{wR}_{2}=0.1287\end{array}$ & $\begin{array}{r}\mathrm{R}_{1}=0.0488 \\
\mathrm{wR}_{2}=0.1082\end{array}$ & $\begin{array}{r}\mathrm{R}_{1}=0.0494 \\
\mathrm{wR}_{2}=0.1180\end{array}$ & $\begin{array}{c}\mathrm{R}_{1}=0.0521 \\
\mathrm{wR}_{2}=0.1228\end{array}$ \\
\hline $\mathrm{R}$ indices (all data) & $\begin{array}{c}\mathrm{R}_{1}=0.0556 ; \\
\mathrm{wR}_{2}=0.1385\end{array}$ & $\begin{array}{c}\mathrm{R}_{1}=0.0811 ; \\
\mathrm{wR}_{2}=0.1436\end{array}$ & $\begin{array}{r}\mathrm{R}_{1}=0.0776 \\
\mathrm{wR}_{2}=0.1262\end{array}$ & $\begin{array}{r}\mathrm{R}_{1}=0.0763 \\
\mathrm{wR}_{2}=0.1329\end{array}$ & $\begin{array}{c}\mathrm{R}_{1}=0.0884 \\
\mathrm{wR}_{2}=0.1499\end{array}$ \\
\hline $\begin{array}{l}\text { Largest diff. Peak } \\
\text { and hole }\end{array}$ & 0.696 and -0.377 & 0.159 and -0.257 & 0.203 and -0.191 & 0.158 and -0.154 & 0.325 and -0.297 \\
\hline CCDC-Number & 1890715 & 1501807 & 1501808 & 1829344 & 1829345 \\
\hline
\end{tabular}


Table 2. Selected bond lengths and angles of compounds $2 \mathbf{h}, 3 \mathbf{a}, 3 \mathbf{b}, 3 \mathbf{c}$ and $\mathbf{3 d}\left(\AA^{\circ}\right.$ and $\left.^{\circ}\right)$.

\begin{tabular}{|c|c|c|c|c|c|}
\hline & \multicolumn{5}{|c|}{ Bond Lengths (Å) } \\
\hline & $2 \mathrm{~h}$ & $3 a$ & $3 b$ & $3 c$ & $3 d$ \\
\hline $\mathrm{C}(10)-\mathrm{N}(2)$ & - & $1.269(6)$ & 1.2741 & $1.265(2)$ & 1.2816 \\
\hline $\mathrm{C}(33)-\mathrm{N}(4)$ & - & $1.421(6)$ & $1.417(2)$ & $1.426(2)$ & 1.4263 \\
\hline$C(5)-C(10)$ & - & $1.459(7)$ & $1.465(2)$ & 1.4631 & 1.4488 \\
\hline$C(5)-C(11)$ & 1.448 & - & - & - & - \\
\hline$C(7)-C(12)$ & 1.452 & - & - & - & - \\
\hline $\mathrm{C}(8)-\mathrm{O}(1)$ & 1.243 & $1.350(5)$ & - & - & 1.341 \\
\hline \multirow[t]{2}{*}{$\mathrm{C}(6)-\mathrm{N}(3)$} & - & - & $1.415(2)$ & $1.403(2)$ & - \\
\hline & \multicolumn{5}{|c|}{ Angles $\left(^{\circ}\right)$} \\
\hline $\mathrm{C}(10)-\mathrm{N}(2)-\mathrm{C}(11)$ & & $116.8(4)$ & $120.5(1)$ & 117.5(1) & 121.18 \\
\hline $\mathrm{C}(5)-\mathrm{C}(10)-\mathrm{N}(2)$ & & $127.2(5)$ & $124.0(1)$ & $126.1(1)$ & 121.52 \\
\hline
\end{tabular}

\subsection{X-ray Studies}

8-Hydroxy-2-methylquinoline-5,7-dicarbaldehyde (2h) crystallizes with chloroform in the Pnma space group (Figure 3). The molecular ring systems are both essentially planar. The packing of the compound $2 \mathrm{~h}$ in the structure is stabilised by parallelly-displaced $\pi-\pi$ stacking interactions, forming a $\pi$-stacking interaction as illustrated in Figure 4 . The centroid-centroid distances is $3.544 \AA$ and the shift distances is $1.451 \AA$. Compound co-crystallised with chloroform is associated through strong $\mathrm{C} 8-\mathrm{O} 1 \mathrm{H} \cdots \mathrm{Cl} 2 \mathrm{C} 13$ hydrogen bonds. In the crystal structure of compound $\mathbf{2 h}$ several intra- and intermolecular hydrogen bonds are observed. To the best of our knowledge, this is first time that the X-ray structure of quinolinecarbaldehyde has been reported.
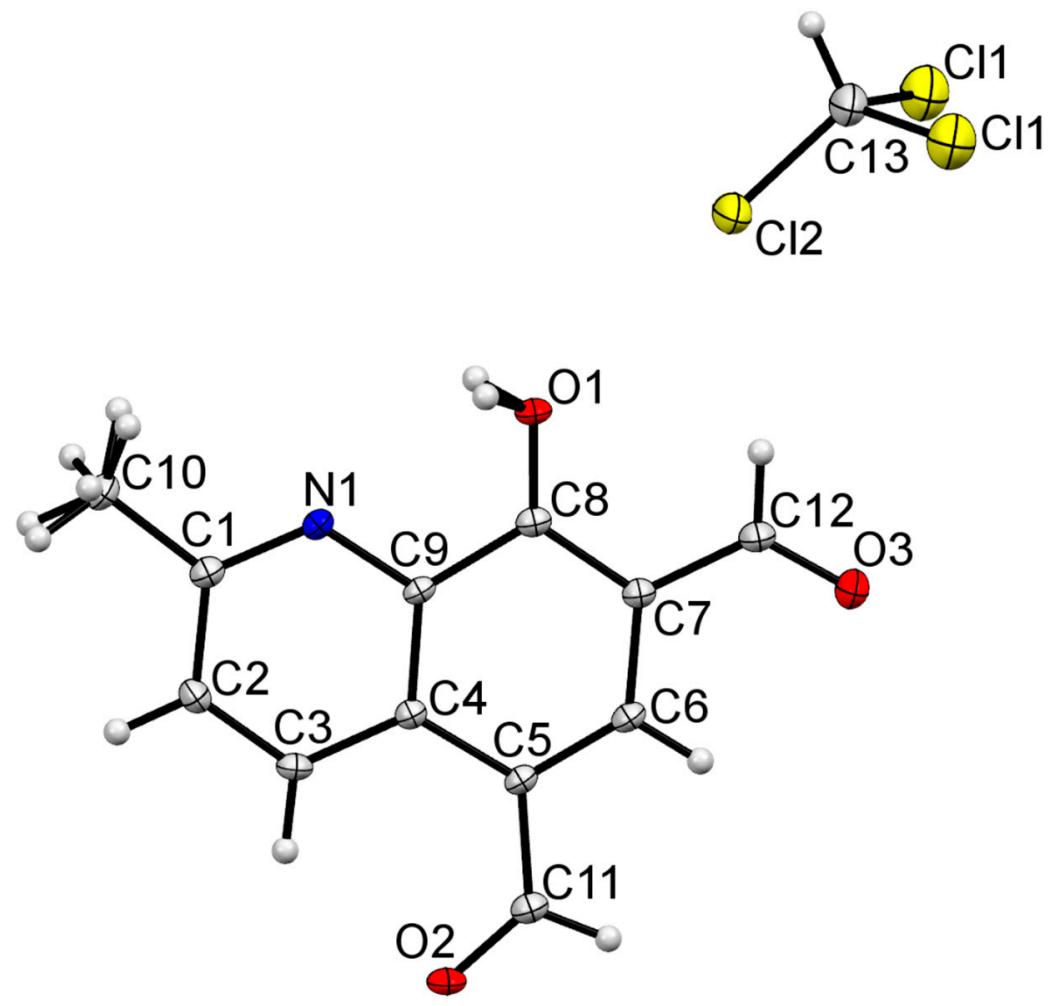

Figure 3. ORTEPs drawing of compound $\mathbf{2 h}$ with $50 \%$ probability displacement ellipsoids. 


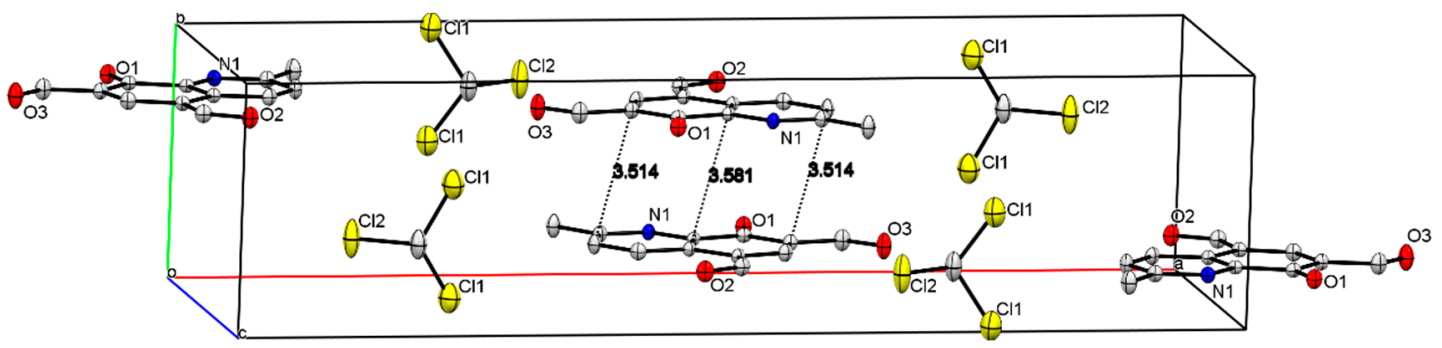

Figure 4. The $\pi$-stacking interactions in cell packing of compound $\mathbf{2 h}$.

The molecules $\mathbf{3 a}, \mathbf{3 b} \mathbf{3} \mathbf{3} \mathbf{c}$ and $\mathbf{3 d}$ were crystallized in the trigonal, orthorhombic, monoclinic and monoclinic space groups, respectively, which are displayed as ORTEP representations in Figure 5. Details concerning crystal data and refinement are gathered in Tables 1 and 2.
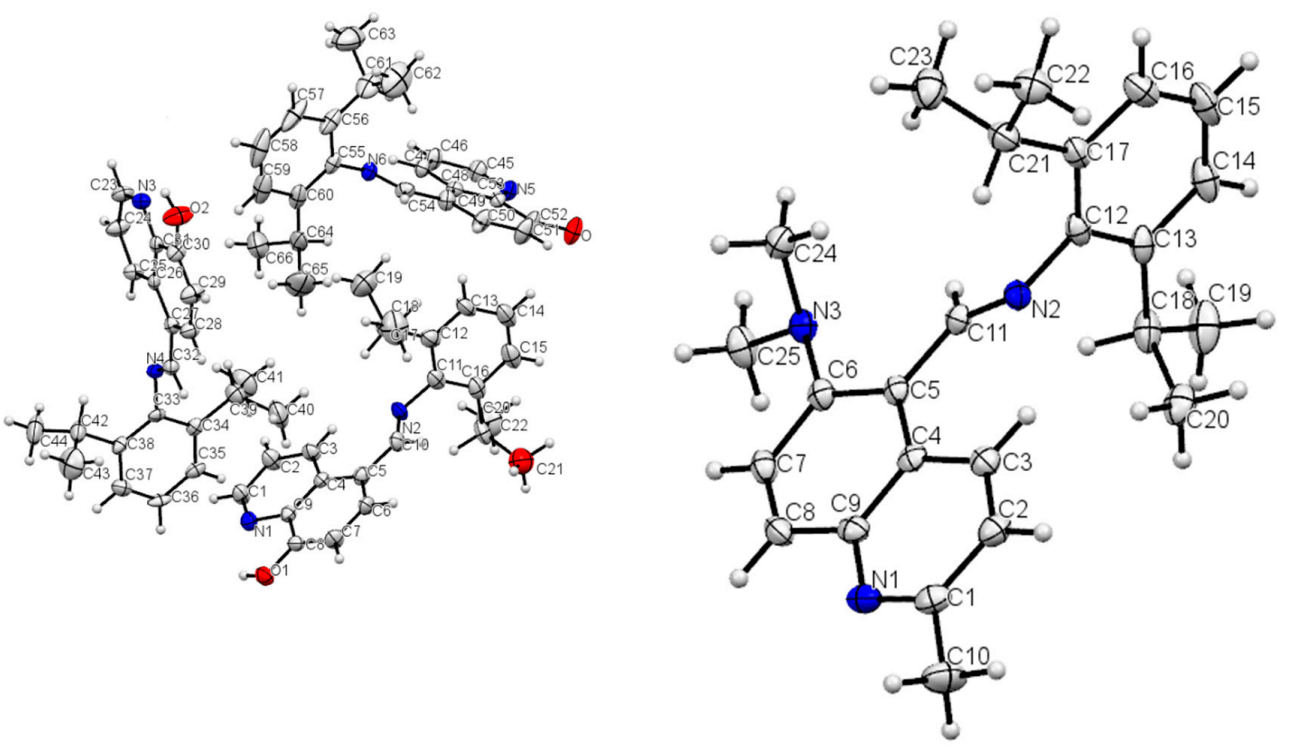

3a

$3 b$

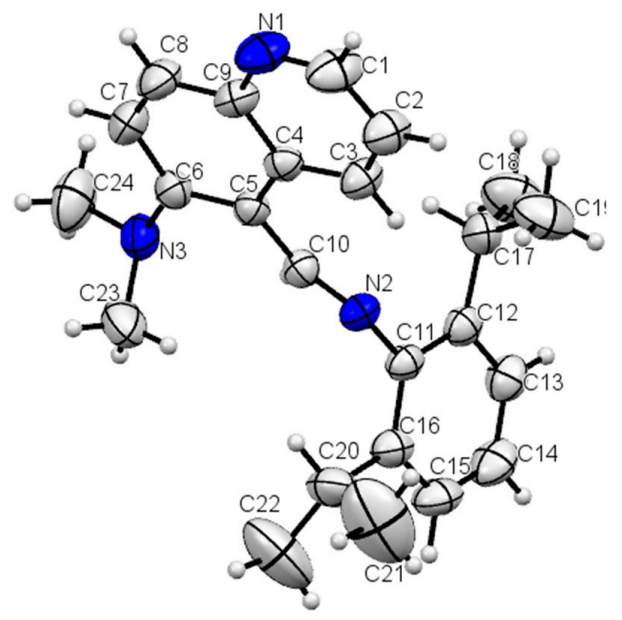

3c

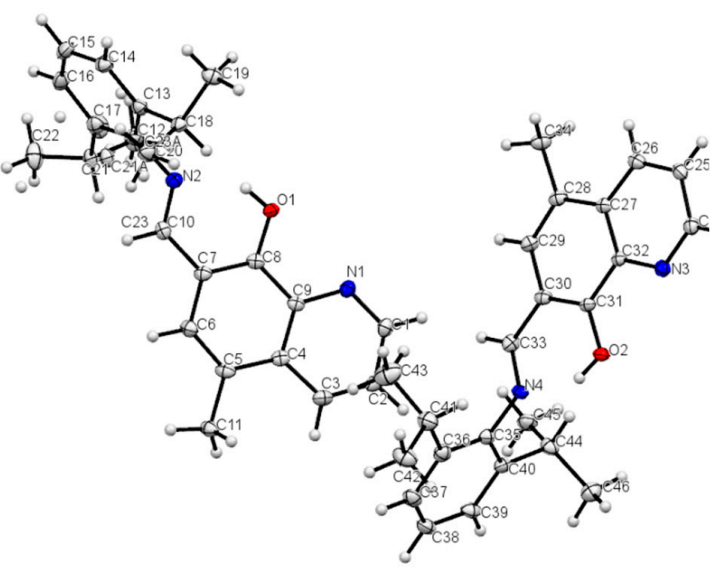

$3 d$

Figure 5. ORTEPs drawing of Schiff bases (3a), (3b), (3c) and (3d) with $50 \%$ probability displacement ellipsoids. 
The phenyl and quinoline rings in the compounds adopt an $E$ configuration along the imino functional group. In the Schiff base compounds both the planes of the quinoline and the phenyl moieties are aligned almost perpendicularly at angles of $89.64^{\circ}(3 \mathbf{a}), 87.51^{\circ}(3 \mathbf{b}), 78.65^{\circ}(3 \mathbf{c})$ and $79.98^{\circ}$ (3d), respectively. The $-\mathrm{C}=\mathrm{N}$ - bond lengths of $1.27 \AA$ are typical $E$ Schiff base compounds $\mathbf{3 a}, \mathbf{3 b}$ and $3 \mathrm{c}$, the $-\mathrm{C}=\mathrm{N}$ - bond length of $1.28 \AA$ for compound $3 \mathrm{~d}$ is longer due to participation in pseudo-ring. The substituents located on the phenol ring in molecule $\mathbf{3} \mathbf{d}$ and on the imino group show their ability to form a pseudo-ring, which is stabilized by intramolecular hydrogen bond indicated on Scheme 5 . The consequence of the formation of pseudo-ring in compound $\mathbf{3 d}$ constitution is the presence of strongest hydrogen bond (O1-H1-N2) among all presented Schiff bases 3. The structures of the presented compounds are stabilized by hydrogen bonds.

\subsection{Electrochemical Measurements}

Electrochemical measurements were performed on a glassy carbon electrode in acetonitrile. Compound $2 \mathrm{a}$ yields three reduction waves in a range of potentials from $0.1 \mathrm{~V}$ to $-2.2 \mathrm{~V}$ (Figure 6A). The first reduction wave at $-1.300 \mathrm{~V}$ is followed by reduction wave 2 at a peak potential $-1.400 \mathrm{~V}$. The charge consumed during the exhaustive electrolysis behind the second reduction wave corresponded to one electron.

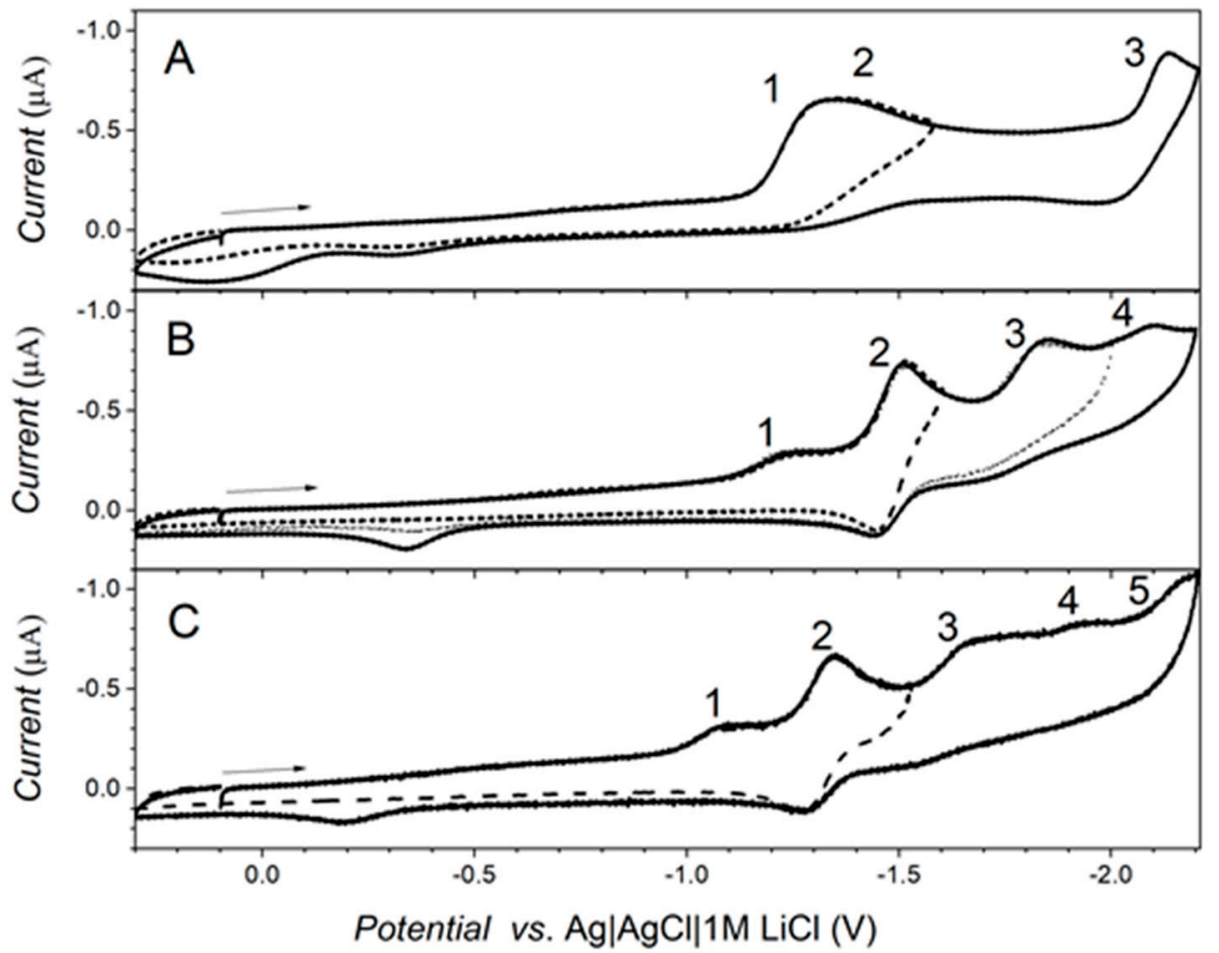

Figure 6. Cyclic voltammograms of $0.2 \mathrm{mM} \mathrm{2a}(\mathbf{A}), \mathbf{2 e}(\mathbf{B})$ and $\mathbf{2 f}(\mathbf{C})$ in acetonitrile and $0.1 \mathrm{M} \mathrm{TBAPF}_{6}$ on glassy carbon electrode.

The third one-electron reduction wave occurred at $-2.133 \mathrm{~V}$, the potentiostatic electrolysis at $-2.1 \mathrm{~V}$ resulted in the consumed charge corresponding to two electrons. Such a discrepancy in number of electrons suggests that the first two reduction waves correspond to different dissociation forms of compound $\mathbf{2 a}$, which are present in solution under experimental conditions; the consumed charge corresponds to the sum of their concentrations. The spatial distribution of LUMO orbitals suggests that carboxyl group accepts the first electron (Figure 7C). The reduction of aldehyde is usually two-electron and two-proton process according to literature [17] We suggest that hydroxyl group present in the chemical structure of compound 2a (Figure 7A) can serve as a proton donor, which participate in reduction process. Such effects were found in literature in the case of reduction of hydroxylated 
benzonitriles, where half molecules present in solution served as proton donors and the charge after the exhaustive electrolysis corresponded to the reduction of half molecules present in solution [18,19]. The study of this effect is not the aim of this manuscript and will be investigated in further study.

A<smiles>O=Cc1ccc(O)c2ncccc12</smiles><smiles>Cc1ccc2c(C=O)c(N(C)C)ccc2n1</smiles><smiles>CN(C)c1ccc2ncccc2c1C=O</smiles>

B
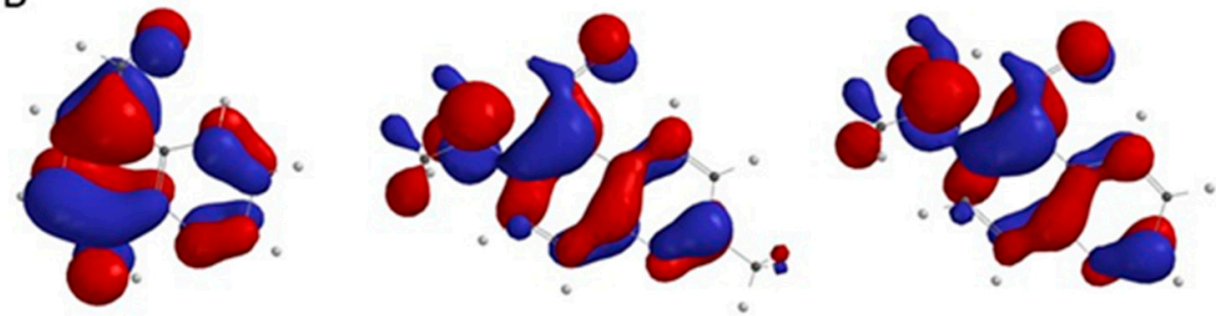

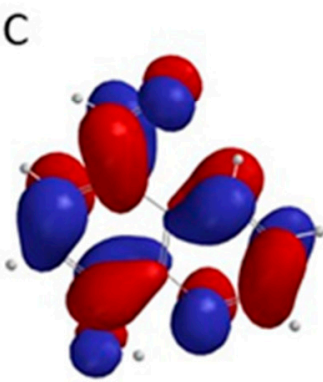

$2 a$

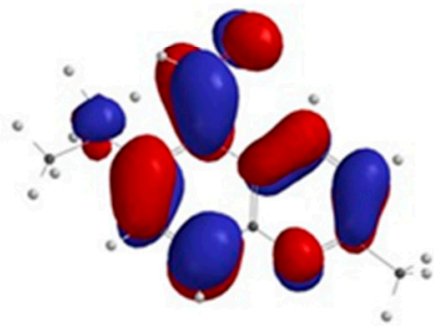

$2 \mathrm{e}$

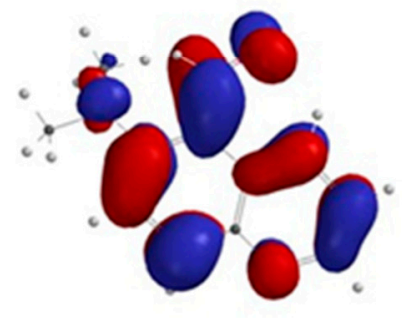

$2 f$

Figure 7. Chemical structures of compounds $2 \mathbf{a}, 2 \mathbf{e}$ and $\mathbf{2 f}(\mathbf{A})$, the spatial distribution of the HOMO orbitals (B) and LUMO orbitals (C).

Cyclic voltammogram obtained for compound 2e yields four reduction waves up to $-2.2 \mathrm{~V}$ (Figure 6B). All reduction waves increase linearly with concentration. The first reduction wave at $-1.233 \mathrm{~V}$ is irreversible, the second one-electron wave at $-1.510 \mathrm{~V}$ is quasi-reversible. The peak-to-peak separation of the wave 2 is $\left|E_{\mathrm{p}}{ }^{\mathrm{c}}-E_{\mathrm{p}}{ }^{\mathrm{a}}\right|=68 \mathrm{mV}$. This behavior is similar to that of compound $\mathbf{2 f}$, which yields five reduction waves in the same range of potentials. The first irreversible reduction wave of $2 \mathbf{f}$ occurs at $-1.087 \mathrm{~V}$ and the second reversible one-electron reduction wave with peak-to-peak separation of $\left|E_{\mathrm{p}}{ }^{\mathrm{c}}-E_{\mathrm{p}}{ }^{\mathrm{a}}\right|=59 \mathrm{mV}$ occurs at $-1.346 \mathrm{~V}$. Most likely, a radical anion is formed at the first reduction wave, it is delocalized over the whole $\pi$-conjugated molecule as shown by LUMO spatial distribution (Figure 7C) and a fast protonation follows. The formed radical can undergo a dimerization process or is further reduced to form corresponding alcohol. The latter can be preferential under used experimental conditions, because the exhaustive electrolysis at the potential behind the second reduction wave resulted in charge consuming corresponding to two electron process. We tend to investigate the reduction mechanism in details in further study. Importantly, the peak potential of the first reduction peak of compound $2 \mathbf{e}$ occurs at more negative potential than $\mathrm{Ep}^{1}$ of compound $2 \mathrm{f}$. The difference is caused by induction effect of methyl group. This agrees with calculated energies of LUMO orbitals for both compounds, which increase in order $E_{\mathrm{LUMO}}(\mathbf{2 e})=-1.89 \mathrm{eV}<E_{\mathrm{LUMO}}(\mathbf{2 f})=-1.97 \mathrm{eV}$.

Oxidation properties were studied by means of cyclic voltammetry (Figure S1, Supplementary material). Cyclic voltammetry of 2a yields two oxidation waves at potentials $1.349 \mathrm{~V}$ and $1.637 \mathrm{~V}$. The charge consumed during the exhaustive electrolysis of compound $2 \mathbf{a}$ at the potential behind the 
first oxidation wave corresponded to two electrons. According to Figure 7B, the electroactive site for oxidation is most likely hydroxyl group in para position to the aldehyde. Compound 2e yields better defined oxidation waves at $E_{1}=1.276 \mathrm{~V}$ and $E_{2}=1.662 \mathrm{~V}$ and oxidation waves at $E_{1}=1.385 \mathrm{~V}$ and $E_{2}=1.765 \mathrm{~V}$ were registered for compound $2 \mathrm{f}$. According to the spatial distribution of HOMO orbitals (Figure 7B) the amine can be oxidized. According to the literature, oxidation can yield a dealkylated product [20], and tail to tail coupling is also known in the literature for dialkylanilines [17]. The energies of HOMO orbitals calculated for the molecule in a vacuum suggest that compound $\mathbf{2 e}$ is more easily oxidized than compound $\mathbf{2 f} ; E_{\mathrm{HOMO}}(\mathbf{2 e})=-5.67 \mathrm{eV}>E_{\mathrm{HOMO}}(\mathbf{2 f})=-5.77 \mathrm{eV}$, which is in agreement with the experimental results.

\section{Materials and Methods}

\subsection{Materials}

All experiments were carried out in an atmosphere of dry argon and flasks were flame dried. Solvents were dried by usual methods (diethyl ether and THF over benzophenone ketyl, $\mathrm{CHCl}_{3}$ and $\mathrm{CH}_{2} \mathrm{Cl}_{2}$ over $\mathrm{P}_{4} \mathrm{O}_{10}$, hexane over sodium-potassium alloy and DMF over molecular sieves) and distilled. Chromatography was carried out on Silica Gel 60 (0.15-0.3 mm, Macherey-Nagel GmbH \& Co. KG, Düren, Germany). 2,2,2-Trifluoroacetic acid (Caution! TFA is a known nigrostriatal neurotoxin, and therefore compounds of this class should be handled using disposable gloves in a properly ventilated hood), 5,7-dibromo-2-methylquinolin-8-ol (1a), hexamethylenetetramine (HMTA), 2,6-diisopropylbenzenamine, 2-methylquinolin-8-ol (1b), 8-hydroxyquinoline (1c) and benzo[ $h]$ quinolin-10-ol (1j) were purchased from Sigma-Aldrich (Poznan, Poland), and were used without further purification. 5-Chloroquinolin-8-ol (1d), N,N-dimethylquinolin-6-amine (1e), 5-methylquinolin-8-ol (1f), N,N,2-trimethylquinolin-6-amine (1g), quinolin-6-ol (1h) and $\mathrm{N}, \mathrm{N}$-dimethylquinolin-8-amine (1i) were synthesized according to our procedures described in the literature [21-24].

\subsection{Instrumentation}

NMR spectra were obtained with Avance 400, 500 and 600 spectrometers (Bruker, Billerica, MA, USA) operating at $600.2,500.2$ or $400.1 \mathrm{MHz}\left({ }^{1} \mathrm{H}\right)$ and $150,125.78$ or $100.5 \mathrm{MHz}\left({ }^{13} \mathrm{C}\right)$ at $21{ }^{\circ} \mathrm{C}$. Chemical shifts referenced to ext. TMS $\left({ }^{1} \mathrm{H},{ }^{13} \mathrm{C}\right)$ or using the residual $\mathrm{CHCl}_{3}$ signal $\left(\delta_{\mathrm{H}} 7.26 \mathrm{ppm}\right)$ and $\mathrm{CDCl}_{3}\left(\delta_{\mathrm{C}} 77.1 \mathrm{ppm}\right)$ as internal references for ${ }^{1} \mathrm{H}$ and ${ }^{13} \mathrm{C}-\mathrm{NMR}$, respectively. Coupling constants are given in Hz. For GC-MS a 7890A gas chromatograph (Agilent Technologies, Wilmington, DE, USA) equipped with a MS (70 eV) $5975 \mathrm{EI} / \mathrm{CI}$ MSD, and a 7693 autosampler with an Agilent HP-5MS capillary column $(30 \mathrm{~m} \times 250 \mu \mathrm{m} \times 0.25 \mu \mathrm{m})$-press. $127.5 \mathrm{kPa}$, total flow $19 \mathrm{~mL} / \mathrm{min}$, col. flow $2 \mathrm{~mL} / \mathrm{min}$, split-7:1, temp. prog. $\left(70{ }^{\circ} \mathrm{C}\right.$-hold $0.5 \mathrm{~min}, 70-290^{\circ} \mathrm{C} / 25^{\circ} \mathrm{C} / \mathrm{min}, 290^{\circ} \mathrm{C}$-hold $6 \mathrm{~min}$ ) was used. The LCMS-IT-TOF analysis was performed on an Agilent 1200 Series binary LC system coupled to a micrOTOF-Q system mass spectrometer (Bruker Daltonics, Bremen, Germany). High-resolution mass spectrometry (HRMS) measurements were performed using a Synapt G2-Si mass spectrometer (Waters, New Castle, DE, USA) equipped with an ESI source and quadrupole-time-of-flight mass analyser. To ensure accurate mass measurements, data were collected in centroid mode and mass was corrected during acquisition using leucine enkephalin solution as an external reference (Lock-Spray ${ }^{\mathrm{TM}}$ ). The results of the measurements were processed using the MassLynx 4.1 software (Waters, Milford, CT, USA) incorporated within the instrument. A iS50 FTIR spectrometer (Nicolet, Waltham, MA, USA) was used for recording spectra in the IR range $4000-400 \mathrm{~cm}^{-1}$. FTIR spectra were recorded on a Perkin Elmer (Schwerzenbach, Switzerland) spectrophotometer in the spectral range $4000-450 \mathrm{~cm}^{-1}$ with the samples in the form of $\mathrm{KBr}$ pellets. Elementary analysis was performed using Vario EL III apparatus (Elementar, Langenselbold, Germany). Melting points were determined on MPA100 OptiMelt melting point apparatus (Stanford Research Systems, Sunnyvale, CA USA) and are uncorrected. 


\subsection{Electrochemical Measurements}

Electrochemical measurements were carried out in $0.1 \mathrm{M} \mathrm{TBAPF}_{6}$ in acetonitrile. Cyclic voltammetry as well as exhaustive electrolysis were performed using a PGSTAT 12 AUTOLAB potentiostat (Metrohm Autolab, Utrecht, The Netherlands). A glassy carbon electrode (diameter $1 \mathrm{~mm}$ ), a platinum net and an $\mathrm{Ag}|\mathrm{AgCl}| 1 \mathrm{M} \mathrm{LiCl}$ electrode were used as the working, the auxiliary and reference electrode, respectively. Oxygen was removed from the solution by passing a stream of argon $(99.998 \%$, Messer, Graz, Austria).

\subsection{Theoretical Calculations}

Calculations of molecular orbital energies were performed using the density functional theory (DFT) calculations employing the B3LYP functional and 6-31G* basis set with Spartan '14, v.1.1.8 software (Wavefunction, Inc. Irvine, CA, USA).

\subsection{General Procedures for Synthesis of Selected Quinolinecarbaldehydes Based on the Reimer- Tiemann Protocol}

Potassium hydroxide $(14.0 \mathrm{~g}$; $250.0 \mathrm{mmol})$ in water $(15 \mathrm{~mL})$ was added into the solution of 1c, 1d or $\mathbf{1 f}(34.5 \mathrm{mmol})$ in ethanol $(20 \mathrm{~mL})$ and the resulting reaction mixture was brought to a gentle reflux. Chloroform $(8.3 \mathrm{~mL} ; 103.5 \mathrm{mmol})$ was then added dropwise to the reaction mixture over the course of $1 \mathrm{~h}$. The resulting red mixture was refluxed for another $3 \mathrm{~h}$, and then was cool down to room temperature. The obtained suspension was acidified by an aqueous solution of hydrochloric acid $(1 \%)$ to $\mathrm{pH}$ ca. 7 , and then volatiles were evaporated under reduced pressure. The resulting solid was dried over $\mathrm{P}_{4} \mathrm{O}_{10}$ and extracted at Soxhlet apparatus (chloroform). From the resulting solution the volatiles were evaporated under reduced pressure, and finally the crude product was purified on a silica gel chromatography with $\mathrm{CH}_{3} \mathrm{Cl} / \mathrm{MeOH}$ (3:1) as eluent, and purified by crystallization from $\mathrm{CH}_{3} \mathrm{Cl} /$ hexane to yield precipitates as follows:

8-Hydroxyquinoline-5-carbaldehyde (2a) beige $0.6 \mathrm{~g}$ (3.5 mmol, 10.1\%) [25]; m.p. = 171.3-171.8 ${ }^{\circ} \mathrm{C}$; ${ }^{1} \mathrm{H}-\mathrm{NMR}$ (DMSO- $\left.d_{6} ; 400.2 \mathrm{MHz}\right) \delta=7.26\left(\mathrm{~d},{ }^{3} \mathrm{~J}_{\mathrm{H}, \mathrm{H}}=8.0 \mathrm{~Hz}, 1 \mathrm{H}\right.$, aromatic), $7.78\left(\mathrm{dd},{ }^{3} J_{\mathrm{H}, \mathrm{H}}=8.6 \mathrm{~Hz}\right.$, ${ }^{4} J_{\mathrm{H}, \mathrm{H}}=4.1 \mathrm{~Hz}, 1 \mathrm{H}$, aromatic), $8.17\left(\mathrm{~d},{ }^{3} J_{\mathrm{H}, \mathrm{H}}=8.1 \mathrm{~Hz}, 1 \mathrm{H}\right.$, aromatic), $8.97\left(\mathrm{dd},{ }^{3} J_{\mathrm{H}, \mathrm{H}}=4.1 \mathrm{~Hz},{ }^{4} J_{\mathrm{H}, \mathrm{H}}\right.$ $=1.6 \mathrm{~Hz}, 1 \mathrm{H}$, aromatic), $9.56\left(\mathrm{dd},{ }^{3} J_{\mathrm{H}, \mathrm{H}}=8.6 \mathrm{~Hz},{ }^{4} J_{\mathrm{H}, \mathrm{H}}=1.6 \mathrm{~Hz}, 1 \mathrm{H}\right.$, aromatic), $10.14(\mathrm{~s}, 1 \mathrm{H}, \mathrm{HC}=\mathrm{O})$; ${ }^{13} \mathrm{C}\left\{{ }^{1} \mathrm{H}\right\}$-NMR (DMSO- $d_{6}$; $\left.100.6 \mathrm{MHz}\right) \delta=110.8,122.4,124.6,126.8,133.0,138.0,140.2,149.0,159.6$, 192.2; GC-MS: $\mathrm{t}_{\mathrm{r}}=6.024 \mathrm{~min}$, (EI) $\mathrm{m} / z$ (rel. int.) $\mathrm{M}^{+}=173(100 \%) ;(\mathrm{M}-\mathrm{HCO})^{+}=144(17 \%)$; UV-Vis (methanol; $\lambda$ [nm] (loge)): 395 (3.04), 322 (3.89), 263 (3.96), 239 (4.40), 210 (4.13); IR (KBr): $3177 v_{\mathrm{OH}}$; $2845 v_{\mathrm{CH}} ; 1663 v_{\mathrm{C}=\mathrm{O}} ; 1474 v_{\mathrm{C}-\mathrm{H}}$.

8-Hydroxyquinoline-7-carbaldehyde (2a') [4] ${ }^{1} \mathrm{H}-\mathrm{NMR}$ (DMSO- $\left.d_{6} ; 400.2 \mathrm{MHz}\right) \delta=7.24\left(\mathrm{~d},{ }^{3} \mathrm{~J}_{\mathrm{H}, \mathrm{H}}=7.9 \mathrm{~Hz}\right.$, $1 \mathrm{H}$, aromatic), $7.57\left(\mathrm{dd},{ }^{3} J_{\mathrm{H}, \mathrm{H}}=8.1 \mathrm{~Hz},{ }^{4} J_{\mathrm{H}, \mathrm{H}}=4.3 \mathrm{~Hz}, 1 \mathrm{H}\right.$, aromatic), $7.99\left(\mathrm{~d},{ }^{3} J_{\mathrm{H}, \mathrm{H}}=8.0 \mathrm{~Hz}\right.$, $1 \mathrm{H}$, aromatic), $8.78\left(\mathrm{dd},{ }^{3} \mathrm{~J}_{\mathrm{H}, \mathrm{H}}=4.4 \mathrm{~Hz},{ }^{4} \mathrm{~J}_{\mathrm{H}, \mathrm{H}}=1.5 \mathrm{~Hz}, 1 \mathrm{H}\right.$, aromatic), $9.07\left(\mathrm{dd},{ }^{3} J_{\mathrm{H}, \mathrm{H}}=8.0 \mathrm{~Hz}\right.$, ${ }^{4} J_{\mathrm{H}, \mathrm{H}}=1.6 \mathrm{~Hz}, 1 \mathrm{H}$, aromatic), 10.41 (s, $1 \mathrm{H}, \mathrm{HC}=\mathrm{O}$ ); GC-MS: $\mathrm{t}_{\mathrm{r}}=6.360 \mathrm{~min}$, (EI) $\mathrm{m} / \mathrm{z}$ (rel. int.) $\mathrm{M}^{+}=173$ $(12 \%) ;(\mathrm{M}-\mathrm{CO}+\mathrm{H})^{+}=146(100 \%)$.

5-Chloro-8-hydroxyquinoline-7-carbaldehyde (2b) yellow $0.5 \mathrm{~g}(2.5 \mathrm{mmol}, 7.2 \%)$ [26]; m.p. $=170.0-170.6{ }^{\circ} \mathrm{C}$; ${ }^{1} \mathrm{H}-\mathrm{NMR}\left(\mathrm{CDCl}_{3} ; 500.18 \mathrm{MHz}\right) \delta=7.71\left(\mathrm{dd},{ }^{3} J_{\mathrm{H}, \mathrm{H}}=8.5 \mathrm{~Hz},{ }^{4} J_{\mathrm{H}, \mathrm{H}}=4.2 \mathrm{~Hz}, 1 \mathrm{H}\right.$, aromatic), 7.86 (s, $1 \mathrm{H}$, aromatic), $8.56\left(\mathrm{dd},{ }^{3} J_{\mathrm{H}, \mathrm{H}}=8.5 \mathrm{~Hz},{ }^{4} J_{\mathrm{H}, \mathrm{H}}=1.5 \mathrm{~Hz}, 1 \mathrm{H}\right.$, aromatic), $8.97\left(\mathrm{dd},{ }^{3} J_{\mathrm{H}, \mathrm{H}}=4.2 \mathrm{~Hz}\right.$, ${ }^{4} J_{\mathrm{H}, \mathrm{H}}=1.5 \mathrm{~Hz}, 1 \mathrm{H}$, aromatic), $10.39(\mathrm{~s}, 1 \mathrm{H}, \mathrm{HC}=\mathrm{O}) ;{ }^{1} \mathrm{H}-\mathrm{NMR}\left(\mathrm{DMSO}-d_{6} ; 500.18 \mathrm{MHz}\right) \delta=7.74$ (s, $1 \mathrm{H}$, aromatic), $7.88\left(\mathrm{dd},{ }^{3} J_{\mathrm{H}, \mathrm{H}}=8.5 \mathrm{~Hz},{ }^{4} J_{\mathrm{H}, \mathrm{H}}=4.2 \mathrm{~Hz}, 1 \mathrm{H}\right.$, aromatic), $8.51\left(\mathrm{dd},{ }^{3} J_{\mathrm{H}, \mathrm{H}}=8.5 \mathrm{~Hz}\right.$, ${ }^{4} J_{\mathrm{H}, \mathrm{H}}=1.4 \mathrm{~Hz}, 1 \mathrm{H}$, aromatic), $9.05\left(\mathrm{dd},{ }^{3} J_{\mathrm{H}, \mathrm{H}}=4.2 \mathrm{~Hz},{ }^{4} J_{\mathrm{H}, \mathrm{H}}=1.4 \mathrm{~Hz}, 1 \mathrm{H}\right.$, aromatic), $10.49(\mathrm{~s}, 1 \mathrm{H}$, $\mathrm{HC}=\mathrm{O}$ ); ${ }^{13} \mathrm{C}\left\{{ }^{1} \mathrm{H}\right\}-\mathrm{NMR}$ (DMSO- $\left.d_{6} ; 125.78 \mathrm{MHz}\right) \delta=118.7,119.8,122.7,125.7,129.3,133.1,140.2,149.9$, 158.4, 188.0; ${ }^{13} \mathrm{C}\left\{{ }^{1} \mathrm{H}\right\}-\mathrm{NMR}\left(\mathrm{CDCl}_{3} ; 125.78 \mathrm{MHz}\right) \delta=117.8,121.8,124.7,125.4,130.2,133.7,139.9,149.9$, 157.6, 190.6; GC-MS: $\mathrm{t}_{\mathrm{r}}=6.917$ min.; (EI) $\mathrm{m} / \mathrm{z}$ (rel. int.) $\mathrm{M}^{+}=207(15 \%) ;(\mathrm{M}-\mathrm{CO})^{+}=179(100 \%)$; UV-Vis 
(metanol; $\lambda$ [nm] $(\log \varepsilon)): 429$ (2.86), 350 (3.27),286 (3.65), 267 (4.03), 248 (3.83), 207 (4.09); IR (KBr): $3344 v_{\mathrm{OH}} ; 2859 v_{\mathrm{CH}} ; 1667 v_{\mathrm{C}=\mathrm{O}} ; 1425 v_{\mathrm{C}-\mathrm{H}}$.

5-Methyl-8-hydroxyquinoline-7-carbaldehyde (2c) greenish $0.5 \mathrm{~g}$; (2.8 mmol, 8.0\%) [27]; m.p. = 172.7-173.5 ${ }^{\circ} \mathrm{C}$; ${ }^{1} \mathrm{H}-\mathrm{NMR}\left(\mathrm{CDCl}_{3} ; 400.2 \mathrm{MHz}\right) \delta=2.56\left(\mathrm{~s}, 3 \mathrm{H}, \mathrm{CH}_{3}\right), 7.53\left(\mathrm{~s}, 1 \mathrm{H}\right.$, aromatic), $7.58\left(\mathrm{dd},{ }^{3} \mathrm{~J}_{\mathrm{H}, \mathrm{H}}=8.2 \mathrm{~Hz}\right.$, ${ }^{4} J_{\mathrm{H}, \mathrm{H}}=3.5 \mathrm{~Hz}, 1 \mathrm{H}$, aromatic), $8.26\left(\mathrm{~d},{ }^{3} J_{\mathrm{H}, \mathrm{H}}=8.3 \mathrm{~Hz}, 1 \mathrm{H}\right.$, aromatic), $8.90\left(\mathrm{~d},{ }^{3} J_{\mathrm{H}, \mathrm{H}}=2.7 \mathrm{~Hz}, 1 \mathrm{H}\right.$, aromatic), $10.36(\mathrm{~s}, 1 \mathrm{H}, \mathrm{HC}=\mathrm{O}) ;{ }^{13} \mathrm{C}\left\{{ }^{1} \mathrm{H}\right\}-\mathrm{NMR}\left(\mathrm{CDCl}_{3} ; 100.6 \mathrm{MHz}\right) \delta=17.9,117.2,124.3,124.7,124.9,131.8,133.0$, 139.5, 148.9, 157.4, 192.3; GC-MS: $\mathrm{t}_{\mathrm{r}}=7.186 \mathrm{~min}$.; (EI) $\mathrm{m} / \mathrm{z}$ (rel. int.) $\mathrm{M}^{+}=187(19 \%) ;(\mathrm{M}-\mathrm{CO})^{+}=159$ (100\%); UV-Vis (metanol; $\lambda$ [nm] (loge)): 452 (2.88), 426 (3.04), 358 (3.51), 291 (3.88), 270 (4.37), 246 (4.05), 207 (4.35); IR (KBr): $3063 v_{\mathrm{OH}} ; 2852 v_{\mathrm{CH}} ; 1686 v_{\mathrm{C}=\mathrm{O}} ; 1426 v_{\mathrm{C}-\mathrm{H}}$.

\subsection{Synthesis of 7-Bromo-8-hydroxy-2-methylquinoline-5-carbaldehyde through a Carbene Insertion Reaction}

Potassium hydroxide $(40.0 \mathrm{~g}$; $714.3 \mathrm{mmol})$ in water $(15 \mathrm{~mL})$ was added into the solution of $\mathbf{1 a}$ $(5.6 \mathrm{~g} ; 18.0 \mathrm{mmol})$ in ethanol $(20 \mathrm{~mL})$. The resulting solution was irradiated $(75 \mathrm{~W})$ and stirred under reflux. Next, chloroform $(30 \mathrm{~mL}, 372.0 \mathrm{mmol})$ was slowly added dropwise over an hour. The resulting red mixture was refluxed for another $16 \mathrm{~h}$, and then cooled down to room temperature. Subsequently the obtained suspension was acidified by an aqueous solution of hydrochloric acid (1\%) to $\mathrm{pH} \mathrm{ca.} \mathrm{7,}$ and then volatiles were evaporated under reduced pressure. The resulting solid was dried over $\mathrm{P}_{4} \mathrm{O}_{10}$ and extracted at Soxhlet apparatus with chloroform. From the resulting solution the volatiles were evaporated under reduced pressure, and finally the crude product was purified on a silica gel chromatography with $\mathrm{CH}_{3} \mathrm{Cl} / \mathrm{MeOH}$ (3:1) as eluent, and purified by crystallization from $\mathrm{CH}_{3} \mathrm{Cl} /$ hexane to yield precipitates as follows:

7-Bromo-8-hydroxy-2-methylquinoline-5-carbaldehyde (2d) $<1 \%$ [26]; ${ }^{1} \mathrm{H}-\mathrm{NMR}$ (DMSO- $d_{6} ; 400.2 \mathrm{MHz}$ ) $\delta=2.77\left(\mathrm{~s}, 3 \mathrm{H}, \mathrm{CH}_{3}\right), 7.73\left(\mathrm{~d},{ }^{3} J_{\mathrm{H}, \mathrm{H}}=8.7 \mathrm{~Hz}, 1 \mathrm{H}\right.$, aromatic), $8.32(\mathrm{~s}, 1 \mathrm{H}$, aromatic $), 9.45\left(\mathrm{~d},{ }^{3} J_{\mathrm{H}, \mathrm{H}}=8.7\right.$ $\mathrm{Hz}, 1 \mathrm{H}$, aromatic), 10.05 (s, 1H, HC=O); GC-MS: $\mathrm{t}_{\mathrm{r}}=7.617$ min.; (EI) $\mathrm{m} / \mathrm{z}$ (rel. int.) $\mathrm{M}^{+}=267(15 \%)$; $(\mathrm{M}-\mathrm{CO}+\mathrm{H})^{+}=238(20 \%)$.

\subsection{General Procedures for Synthesis of Selected Quinoline-5-carbaldehydes Based on Vilsmeier-Haack Protocol}

To the solution of dry chloroform $(6.5 \mathrm{~mL})$ and dry DMF $(0.8 \mathrm{~mL}, 32.0 \mathrm{mmol}) \mathrm{POCl}_{3}(3.2 \mathrm{~mL}$, $4.0 \mathrm{mmol})$ was added at $0^{\circ} \mathrm{C}$ and the mixture was stirred for an hour. Next $\mathbf{1 b}, \mathbf{1 e}, \mathbf{1} \mathbf{g}$ or $1 \mathbf{i}(8.0 \mathrm{mmol})$, respectively was added, and the resulting reaction mixture was brought to a gentle reflux for $16 \mathrm{~h}$. The reaction was quenched by the addition of crushed ice and was neutralized by aqueous solution of $\mathrm{Na}_{2} \mathrm{CO}_{3}(10 \%)$ to $\mathrm{pH} 6-7$ and then the layers were separated. The aqueous layer was extracted by chloroform $(3 \times 30 \mathrm{~mL})$, collected, and was dried over anhydrous $\mathrm{MgSO}_{4}$. After filtration, the solvent was evaporated on a rotary evaporator and the obtained residue was purified by column chromatography on silica gel with $\mathrm{CH}_{3} \mathrm{Cl} / \mathrm{THF} /$ hexane (2:1:1) as eluent.

6-(Dimethylamino)-2-methylquinoline-5-carbaldehyde (2e) yellow $0.7 \mathrm{~g}(3.1 \mathrm{mmol}, 38.6 \%)$; m.p. $=75.2-75.8^{\circ} \mathrm{C}$; ${ }^{1} \mathrm{H}-\mathrm{NMR}\left(\mathrm{DMSO}-d_{6} ; 400.2 \mathrm{MHz}\right) \delta=2.58\left(\mathrm{~s}, 3 \mathrm{H}, \mathrm{CH}_{3}\right), 3.11\left(\mathrm{~s}, 6 \mathrm{H}, 2 \mathrm{NCH}_{3}\right), 7.43\left(\mathrm{~d},{ }^{3} \mathrm{~J}_{\mathrm{H}, \mathrm{H}}=8.8 \mathrm{~Hz}, 1 \mathrm{H}\right.$, aromatic), $7.64\left(\mathrm{~d},{ }^{3} J_{\mathrm{H}, \mathrm{H}}=9.4 \mathrm{~Hz}, 1 \mathrm{H}\right.$, aromatic), $7.98\left(\mathrm{~d},{ }^{3} J_{\mathrm{H}, \mathrm{H}}=9.4 \mathrm{~Hz}, 1 \mathrm{H}\right.$, aromatic), $9.18\left(\mathrm{~d},{ }^{3} J_{\mathrm{H}, \mathrm{H}}=8.8 \mathrm{~Hz}\right.$, $1 \mathrm{H}$, aromatic), $10.20(\mathrm{~s}, 1 \mathrm{H}, \mathrm{HC}=\mathrm{O}) ;{ }^{13} \mathrm{C}\left\{{ }^{1} \mathrm{H}\right\}-\mathrm{NMR}$ (DMSO- $\left.d_{6} ; 100.6 \mathrm{MHz}\right) \delta=24.2,45.7,114.8,121.9,124.1$, 125.2, 131.4, 135.2, 142.4, 155.6, 157.1, 190.4; GC-MS: $\mathrm{t}_{\mathrm{r}}=7.683 \mathrm{~min}$, (EI) $\mathrm{m} / \mathrm{z}$ (rel. int.) $\mathrm{M}^{+}=214(85 \%)$; $(\mathrm{M}-\mathrm{HCO})^{+}=185(55 \%) ; \mathrm{UV}-\mathrm{Vis}$ (methanol; $\lambda$ [nm] (loge)): 416 (3.55), 365 (3.12), 304 (3.60), 289 (3.68), 260 (4.35), 214 (4.21); IR (KBr): $3386 v_{\mathrm{OH}} ; 2878 v_{\mathrm{CH}} ; 1671 v_{\mathrm{C}=\mathrm{O}} ; 1498 v_{\mathrm{C}-\mathrm{H}}$.

6-(Dimethylamino)quinoline-5-carbaldehyde (2f) yellow $1.2 \mathrm{~g}(5.9 \mathrm{mmol}, 73.8 \%) ; \mathrm{m} . \mathrm{p} .=56.1-56.8^{\circ} \mathrm{C}$; ${ }^{1} \mathrm{H}-\mathrm{NMR}\left(\mathrm{DMSO}-d_{6} ; 400.2 \mathrm{MHz}\right) \delta=3.16\left(\mathrm{~s}, 6 \mathrm{H}, 2 \mathrm{NCH}_{3}\right), 7.54\left(\mathrm{dd},{ }^{3} J_{\mathrm{H}, \mathrm{H}}=8.7 \mathrm{~Hz},{ }^{4} J_{\mathrm{H}, \mathrm{H}}=4.2\right.$ $\mathrm{Hz}, 1 \mathrm{H}$, aromatic), $7.70\left(\mathrm{~d},{ }^{3} \mathrm{~J}_{\mathrm{H}, \mathrm{H}}=9.5 \mathrm{~Hz}, 1 \mathrm{H}\right.$, aromatic), $8.05\left(\mathrm{~d},{ }^{3} J_{\mathrm{H}, \mathrm{H}}=9.4 \mathrm{~Hz}, 1 \mathrm{H}\right.$, aromatic), $8.69\left(\mathrm{dd},{ }^{3} J_{\mathrm{H}, \mathrm{H}}=4.2 \mathrm{~Hz},{ }^{4} J_{\mathrm{H}, \mathrm{H}}=1.6 \mathrm{~Hz}, 1 \mathrm{H}\right.$, aromatic), $9.30\left(\mathrm{dd},{ }^{3} J_{\mathrm{H}, \mathrm{H}}=8.7 \mathrm{~Hz},{ }^{4} J_{\mathrm{H}, \mathrm{H}}=1.5 \mathrm{~Hz}, 1 \mathrm{H}\right.$, aromatic), $10.19(\mathrm{~s}, 1 \mathrm{H}, \mathrm{HC}=\mathrm{O}) ;{ }^{13} \mathrm{C}\left\{{ }^{1} \mathrm{H}\right\}-\mathrm{NMR}$ (DMSO- $\left.d_{6} ; 125.8 \mathrm{MHz}\right) \delta=45.5,113.4,122.7,123.6$, $127.5,132.0,134.7,141.6,146.6,157.5,190.0$; GC-MS: $\mathrm{t}_{\mathrm{r}}=7.259 \mathrm{~min},(\mathrm{EI}) \mathrm{m} / \mathrm{z}$ (rel. int.) $\mathrm{M}^{+}=200(76 \%)$; 
$(\mathrm{M}-\mathrm{HCO})^{+}=171(20 \%)$; UV-Vis (methanol; $\lambda$ [nm] (loge)): 423 (3.61), 373 (3.18), $307(3.60), 268$ (4.33), 222 (4.17), 204 (3.96); IR (KBr): $3421 v_{\mathrm{OH}} ; 2895 v_{\mathrm{CH}} ; 1636 v_{\mathrm{C}=\mathrm{O}} ; 1458 v_{\mathrm{C}-\mathrm{H}}$.

8-(Dimethylamino)quinoline-5-carbaldehyde (2i) yellow $0.01 \mathrm{~g}(0.05 \mathrm{mmol}, 0.6 \%) ; \mathrm{m} . \mathrm{p} .=100.8-101.0^{\circ} \mathrm{C}$; ${ }^{1} \mathrm{H}-\mathrm{NMR}\left(\mathrm{CDCl}_{3} ; 400.2 \mathrm{MHz}\right) \delta=3.36\left(\mathrm{~s}, 6 \mathrm{H}, 2 \mathrm{NCH}_{3}\right), 6.97\left(\mathrm{~d},{ }^{3} \mathrm{~J}_{\mathrm{H}, \mathrm{H}}=8.2 \mathrm{~Hz}, 1 \mathrm{H}\right.$, aromatic), $7.53\left(\mathrm{dd},{ }^{3} J_{\mathrm{H}, \mathrm{H}}=8.6 \mathrm{~Hz},{ }^{4} J_{\mathrm{H}, \mathrm{H}}=4.1 \mathrm{~Hz}, 1 \mathrm{H}\right.$, aromatic), $7.84\left(\mathrm{~d},{ }^{3} J_{\mathrm{H}, \mathrm{H}}=8.3 \mathrm{~Hz}, 1 \mathrm{H}\right.$, aromatic), $8.87\left(\mathrm{dd},{ }^{3} J_{\mathrm{H}, \mathrm{H}}=4.0 \mathrm{~Hz},{ }^{4} J_{\mathrm{H}, \mathrm{H}}=1.7 \mathrm{~Hz}, 1 \mathrm{H}\right.$, aromatic), $9.72\left(\mathrm{dd},{ }^{3} J_{\mathrm{H}, \mathrm{H}}=8.6 \mathrm{~Hz},{ }^{4} J_{\mathrm{H}, \mathrm{H}}=1.7 \mathrm{~Hz}, 1 \mathrm{H}\right.$, aromatic), $10.06(\mathrm{~s}, 1 \mathrm{H}, \mathrm{HC}=\mathrm{O}) ;{ }^{13} \mathrm{C}\left\{{ }^{1} \mathrm{H}\right\}-\mathrm{NMR}\left(\mathrm{CDCl}_{3} ; 125.8 \mathrm{MHz}\right) \delta=44.1,111.2,122.2,123.3,128.3$, 133.9, 139.5, 141.0, 146.9, 155.0, 191.3; GC-MS: $\mathrm{t}_{\mathrm{r}}=7.156 \mathrm{~min}$, (EI) $\mathrm{m} / \mathrm{z}$ (rel. int.) $\mathrm{M}^{+}=200.1(24 \%)$, $(\mathrm{M}-\mathrm{Me})^{+}=185.1(100 \%),(\mathrm{M}-\mathrm{HCO})^{+}=171.1(38 \%) ; \mathrm{UV}-V i s($ methanol; $\lambda[\mathrm{nm}](\log \varepsilon)): 390(4.07)$, 289 (3.91), 263 (4.20), 234 (3.99), 206 (4.36); IR (KBr): $2840 v_{\mathrm{CH}} ; 1665 v_{\mathrm{C}=\mathrm{O}} ; 1555 ; 1509 v_{\mathrm{C}-\mathrm{H}} ; 1352 ; 1251$; $1080 ; 760$.

8-(Dimethylamino)quinoline-5,7-dicarbaldehyde (2j) yellow $0.006 \mathrm{~g}(0.002 \mathrm{mmol}, 0.3 \%) ; \mathrm{m} . \mathrm{p} .=100.0-100.1^{\circ} \mathrm{C}$; ${ }^{1} \mathrm{H}-\mathrm{NMR}\left(\mathrm{CDCl}_{3} ; 400.2 \mathrm{MHz}\right) \delta=3.61\left(\mathrm{~s}, 6 \mathrm{H}, 2 \mathrm{NCH}_{3}\right), 7.57\left(\mathrm{dd},{ }^{3} J_{\mathrm{H}, \mathrm{H}}=8.6 \mathrm{~Hz},{ }^{4} J_{\mathrm{H}, \mathrm{H}}=4.1 \mathrm{~Hz}, 1 \mathrm{H}\right.$, aromatic), $8.26\left(\mathrm{~s}, 1 \mathrm{H}\right.$, aromatic), $8.88\left(\mathrm{~d},{ }^{3} J_{\mathrm{H}, \mathrm{H}}=4.1 \mathrm{~Hz},{ }^{4} \mathrm{~J}_{\mathrm{H}, \mathrm{H}}=1.7 \mathrm{~Hz}, 1 \mathrm{H}\right.$, aromatic), $9.70\left(\mathrm{dd},{ }^{3} \mathrm{~J}_{\mathrm{H}, \mathrm{H}}=8.6 \mathrm{~Hz}\right.$, ${ }^{4} J_{\mathrm{H}, \mathrm{H}}=1.7 \mathrm{~Hz}, 1 \mathrm{H}$, aromatic), $10.06(\mathrm{~s}, 1 \mathrm{H}, \mathrm{HC}=\mathrm{O}), 10.17(\mathrm{~s}, 1 \mathrm{H}, \mathrm{HC}=\mathrm{O}) ;{ }^{13} \mathrm{C}\left\{{ }^{1} \mathrm{H}\right\}-\mathrm{NMR}\left(\mathrm{CDCl}_{3} ; 125.8 \mathrm{MHz}\right)$ $\delta=48.3,122.1,122.6,124.7,130.2,134.0,141.9,144.4,147.5,157.0,188.5,191.3$; GC-MS: $\mathrm{t}_{\mathrm{r}}=7.952 \mathrm{~min},(\mathrm{EI}) \mathrm{m} / \mathrm{z}$ (rel. int.) $\mathrm{M}^{+}=227.9(100 \%),(\mathrm{M}-\mathrm{Me})^{+}=213.0(3 \%),(\mathrm{M}+2 \mathrm{H}-\mathrm{CO})^{+}=202(10 \%)$; LCMS-IT-TOF: $\mathrm{m} / \mathrm{z}$ (rel. int.) $(\mathrm{M}+\mathrm{H})^{+}=229(100 \%),(\mathrm{M}+\mathrm{H}-\mathrm{CO})^{+}=201(100 \%)$; HRMS (IT-TOF): $\mathrm{m} / \mathrm{z}$ Calcd for $\mathrm{C}_{13} \mathrm{H}_{13} \mathrm{~N}_{2} \mathrm{O}_{2}$ $(\mathrm{M}+\mathrm{H})^{+}=229.0977$, Found 229.0970; UV-Vis (methanol; $\lambda$ [nm] $\left.(\log \varepsilon)\right): 400$ (4.33), 355 (4.04), 287 (4.38), 234 (4.33), 210 (4.33); IR (KBr): $2872 v_{\mathrm{CH}} ; 1678 v_{\mathrm{C}=\mathrm{O}} ; 1661 v_{\mathrm{C}=\mathrm{O}} ; 1515 v_{\mathrm{C}-\mathrm{H}} ; 1381,1265,1103,765$.

(Z)-8-Hydroxy-2-(2-hydroxyvinyl)quinoline-5-carbaldehyde (21) yellow $0.6 \mathrm{~g}$ (2.6 mmol, 32.1\%); m.p. $=153.1-153.8^{\circ} \mathrm{C} ;{ }^{1} \mathrm{H}-\mathrm{NMR}\left(\mathrm{DMSO}-d_{6} ; 400.2 \mathrm{MHz}\right) \delta=7.28\left(\mathrm{dd},{ }^{3} J_{\mathrm{H}, \mathrm{H}}=5.7 \mathrm{~Hz},{ }^{4} J_{\mathrm{H}, \mathrm{H}}=3.2 \mathrm{~Hz}\right.$, $1 \mathrm{H}$, aromatic), 7.45-7.48 (m, $2 \mathrm{H}$, aromatic), $8.58\left(\mathrm{~d},{ }^{3} J_{\mathrm{H}, \mathrm{H}}=9.3 \mathrm{~Hz}, 1 \mathrm{H}\right.$, aromatic), $8.86\left(\mathrm{~d},{ }^{3} J_{\mathrm{H}, \mathrm{H}}=9.2 \mathrm{~Hz}\right.$, $1 \mathrm{H}$, aromatic), $9.43(\mathrm{~s}, 2 \mathrm{H}, \mathrm{HC}=\mathrm{O}), 11.42(\mathrm{~s}, 1 \mathrm{H}, \mathrm{OH}), 16.14(\mathrm{~s}, 1 \mathrm{H}, \mathrm{OH}) ;{ }^{13} \mathrm{C}\left\{{ }^{1} \mathrm{H}\right\}-\mathrm{NMR}$ (DMSO- $d_{6}$; $125.8 \mathrm{MHz}) \delta=106.4,115.1,118.0,118.1,125.4,125.9,126.9,142.1,146.4,150.7,189.6,191.8$; LCMS-IT-TOF: $m / z$ (rel. int.) $(\mathrm{M}+\mathrm{H})^{+}=216(100 \%)$; HRMS (IT-TOF): $\mathrm{m} / \mathrm{z}$ Calcd for $\mathrm{C}_{12} \mathrm{H}_{10} \mathrm{NO}_{3}(\mathrm{M}+\mathrm{H})^{+}=216.0660$, Found 216.0665; UV-Vis (methanol; $\lambda$ [nm] $(\log \varepsilon)$ ): 402 (3.91), 382 (3.99), 297 (4.28), 262 (4.07), 241 (4.21), 214 (4.39); IR (KBr): $3102 v_{\mathrm{OH}} ; 2906 v_{\mathrm{CH}} ; 1594 v_{\mathrm{C}=\mathrm{O}} ; 1353 v_{\mathrm{C}-\mathrm{H}}$.

\subsection{General Procedures for the Synthesis of Selected Quinolinecarbaldehydes Based on the Duff Protocol}

These were based on a procedure described in the literature [28]. To a solution of $\mathbf{1 b}, \mathbf{1 d}, \mathbf{1 e}, \mathbf{1 f}, \mathbf{1 h}$ or $\mathbf{1 j}(5.0 \mathrm{mmol})$ in a minimum amount of TFA $(7-8 \mathrm{~mL})$ hexamethylenetetramine $(1.4 \mathrm{~g}, 10.0 \mathrm{mmol})$ was gently added under an argon atmosphere. The solution was stirred at $70{ }^{\circ} \mathrm{C}$ for $70 \mathrm{~h}$ and then at $100{ }^{\circ} \mathrm{C}$ for another $4 \mathrm{~h}$. Subsequently, the obtained suspension was acidified by an aqueous solution of hydrochloric acid $(10 \%, \sim 10 \mathrm{~mL})$ and the reaction mixture was kept at $100{ }^{\circ} \mathrm{C}$ for $1 \mathrm{~h}$. The whole suspension was cooled down to r.t. Next, the obtained reaction mixture was alkalified by aqueous solution of $\mathrm{NaOH}(10 \%)$, and the resulting precipitate was collected in a Buchner funnel, followed by washing with water $(3 \times 50 \mathrm{~mL})$ and dried to afford a solid. Next, the crude product was purified by chromatography to yield 2c precipitates as follows, or the crude product was extracted with $\mathrm{CH}_{2} \mathrm{Cl}_{2}$ at Soxhlet apparatus to yield $\mathbf{2 h}$ solid as follows:

5-Chloro-8-hydroxyquinoline-7-carbaldehyde (2b) $0.7 \mathrm{~g}$ (3.5 mmol, 70\%).

5-Methyl-8-hydroxyquinoline-7-carbaldehyde (2c) $0.7 \mathrm{~g}$ (3.7 mmol; 75.0\%).

6-Hydroxyquinoline-5-carbaldehyde (2g) beige $0.6 \mathrm{~g}$ (3.5 mmol, 28.1\%) [29]; m.p. = 138.6-138.9 ${ }^{\circ} \mathrm{C}$; ${ }^{1} \mathrm{H}-\mathrm{NMR}\left(\mathrm{CDCl}_{3} ; 400.2 \mathrm{MHz}\right) \delta=7.39\left(\mathrm{~d},{ }^{3} J_{\mathrm{H}, \mathrm{H}}=9.3 \mathrm{~Hz}, 1 \mathrm{H}\right.$, aromatic), $7.53\left(\mathrm{dd},{ }^{3} J_{\mathrm{H}, \mathrm{H}}=8.6 \mathrm{~Hz}\right.$, ${ }^{4} J_{\mathrm{H}, \mathrm{H}}=4.2 \mathrm{~Hz}, 1 \mathrm{H}$, aromatic), $8.26\left(\mathrm{~d},{ }^{3} J_{\mathrm{H}, \mathrm{H}}=9.3 \mathrm{~Hz}, 1 \mathrm{H}\right.$, aromatic), $8.67\left(\mathrm{~d},{ }^{3} J_{\mathrm{H}, \mathrm{H}}=8.6 \mathrm{~Hz}, 1 \mathrm{H}\right.$, aromatic), $8.85\left(\mathrm{~d},{ }^{3} \mathrm{~J}_{\mathrm{H}, \mathrm{H}}=3.1 \mathrm{~Hz}, 1 \mathrm{H}\right.$, aromatic), $10.76(\mathrm{~s}, 1 \mathrm{H}, \mathrm{HC}=\mathrm{O}), 13.06(\mathrm{~s}, 1 \mathrm{H}, \mathrm{OH}) ;{ }^{13} \mathrm{C}\left\{{ }^{1} \mathrm{H}\right\}-\mathrm{NMR}$ $\left(\mathrm{CDCl}_{3} ; 100.6 \mathrm{MHz}\right) \delta=110.7,123.1,123.5,127.0,128.2,140.7,143.4,148.7,164.9,192.4$; GC-MS: 
$\mathrm{t}_{\mathrm{r}}=6.168 \mathrm{~min},(\mathrm{EI}) \mathrm{m} / \mathrm{z}$ (rel. int.) $\mathrm{M}^{+}=173(100 \%) ;(\mathrm{M}-\mathrm{HCO})^{+}=144(20 \%) ; \mathrm{UV}-\mathrm{Vis}$ (methanol; $\lambda$ [nm] $(\log \varepsilon)): 400$ (2.46), 346 (3.16), 300 (3.43), 290 (3.37), 226 (4.04), 203 (0.98); IR (KBr): $3050 v_{\mathrm{OH}} ; 2733 v_{\mathrm{CH}}$; $1632 v_{\mathrm{C}=\mathrm{O}} ; 1480 v_{\mathrm{C}-\mathrm{H}}$.

8-Hydroxy-2-methylquinoline-5,7-dicarbaldehyde (2h) red $0.2 \mathrm{~g}(0.7 \mathrm{mmol}, 14.9 \%)$; m.p. $>360{ }^{\circ} \mathrm{C} ;{ }^{1} \mathrm{H}$-NMR $\left(\right.$ DMSO- $\left.d_{6} ; 400.2 \mathrm{MHz}\right) \delta=2.85\left(\mathrm{~s}, 3 \mathrm{H}, \mathrm{CH}_{3}\right), 7.92\left(\mathrm{~d},{ }^{3} \mathrm{~J}_{\mathrm{H}, \mathrm{H}}=8.7 \mathrm{~Hz}, 1 \mathrm{H}\right.$, aromatic), $8.29(\mathrm{~s}, 1 \mathrm{H}$, aromatic), $9.71\left(\mathrm{~d},{ }^{3} \mathrm{~J}_{\mathrm{H}, \mathrm{H}}=8.7 \mathrm{~Hz}, 1 \mathrm{H}\right.$, aromatic), $9.95(\mathrm{~s}, 1 \mathrm{H}, \mathrm{HC}=\mathrm{O}), 10.42(\mathrm{~s}, 1 \mathrm{H}, \mathrm{HC}=\mathrm{O}) ;{ }^{13} \mathrm{C}\left\{{ }^{1} \mathrm{H}\right\}-\mathrm{NMR}$ (DMSO- $d_{6}$; $\left.125.8 \mathrm{MHz}\right) \delta=21.6,115.6,119.5,128.0,128.6,137.8,138.5,139.0,155.7,167.2,188.2,191.5$; LCMS-IT-TOF: $m / z$ (rel. int.) $(\mathrm{M}-\mathrm{H})^{-}=214(100 \%), \mathrm{M}^{-}=215(10 \%) ;(\mathrm{M}-\mathrm{HCO})^{-}=186(10 \%)$; $(\mathrm{M}-2 \mathrm{HCO})^{-}=157(<1 \%) ; \mathrm{HRMS}$ (IT-TOF): $\mathrm{m} / z$ Calcd for $\mathrm{C}_{12} \mathrm{H}_{8} \mathrm{NO}_{3}(\mathrm{M}-\mathrm{H})^{-}=214.0504$, Found 214.0496; UV-Vis (methanol; $\lambda$ [nm] (loge)): 359 (3.65), 282 (3.91), 237 (3.59); IR (KBr): $3423 v_{\mathrm{OH}}$; $2965 v_{\mathrm{CH}} ; 2847 v_{\mathrm{CH}} ; 2835 v_{\mathrm{CH}} ; 1657 v_{\mathrm{C}=\mathrm{O}} ; 1458 v_{\mathrm{C}-\mathrm{H}} ; \mathrm{CCDC} 1890715$.

10-hydroxybenzo[h]quinoline-7,9-dicarbaldehyde (2k) red $0.9 \mathrm{~g}(3.5 \mathrm{mmol}, 70.6 \%)$; m.p.dec. $>360{ }^{\circ} \mathrm{C}$; ${ }^{1} \mathrm{H}-\mathrm{NMR}\left(\mathrm{DMSO}-d_{6} / \mathrm{KOD} / \mathrm{D}_{2} \mathrm{O} ; 400.2 \mathrm{MHz}\right) \delta=7.51\left(\mathrm{dd},{ }^{3} J_{\mathrm{H}, \mathrm{H}}=8.0 \mathrm{~Hz},{ }^{4} J_{\mathrm{H}, \mathrm{H}}=4.2 \mathrm{~Hz}, 1 \mathrm{H}\right.$, aromatic), $7.96\left(\mathrm{~d},{ }^{3} J_{\mathrm{H}, \mathrm{H}}=9.0 \mathrm{~Hz}, 1 \mathrm{H}\right.$, aromatic), $8.10\left(\mathrm{~s}, 1 \mathrm{H}\right.$, aromatic), $8.26\left(\mathrm{dd},{ }^{3} J_{\mathrm{H}, \mathrm{H}}=8.1 \mathrm{~Hz},{ }^{4} J_{\mathrm{H}, \mathrm{H}}=2.0 \mathrm{~Hz}\right.$, $1 \mathrm{H}$, aromatic), $8.89\left(\mathrm{dd},{ }^{3} J_{\mathrm{H}, \mathrm{H}}=4.2 \mathrm{~Hz},{ }^{4} J_{\mathrm{H}, \mathrm{H}}=2.0 \mathrm{~Hz}, 1 \mathrm{H}\right.$, aromatic), $9.20\left(\mathrm{~d},{ }^{3} J_{\mathrm{H}, \mathrm{H}}=9.0 \mathrm{~Hz}, 1 \mathrm{H}\right.$, aromatic), $9.65(\mathrm{~s}, 1 \mathrm{H}, \mathrm{HC}=\mathrm{O}), 10.08(\mathrm{~s}, 1 \mathrm{H}, \mathrm{HC}=\mathrm{O}) ;{ }^{13} \mathrm{C}\left\{{ }^{1} \mathrm{H}\right\}-\mathrm{NMR}\left(\mathrm{DMSO}-d_{6} / \mathrm{KOD} / \mathrm{D}_{2} \mathrm{O} ; 125.8 \mathrm{MHz}\right)$ $\delta=115.1,122.2,123.8,124.8,126.1,126.9,132.3,137.4,140.0,144.6,148.1,151.1,182.0,192.6,192.7 ;$ HRMS (ESI): $\mathrm{m} / z$ Calcd for $\mathrm{C}_{15} \mathrm{H}_{9} \mathrm{NO}_{3} \mathrm{M}^{-}=251.05826$, Found 251.07750; UV-Vis (methanol; $\lambda$ [nm] $(\log \varepsilon)): 453$ (2.41), 405 (3.22), 364 (3.38), 329 (3.46), 315 (3.48), 274 (3.96), 260 (4.03), 241 (4.02), 223 (4.01), 211 (4.04); IR (KBr): $3424 v_{\mathrm{OH}} ; 3062 v_{\mathrm{CH}} ; 2877 v_{\mathrm{CH}} ; 1673 v_{\mathrm{C}=\mathrm{O}} ; 1483 v_{\mathrm{C}-\mathrm{H}}$.

10-Hydroxybenzo[h]quinoline-7-carbaldehyde [30] $<1 \%$.

10-Hydroxybenzo[h]quinoline-9-carbaldehyde [31] $<1 \%$.

\subsection{General Procedure the for Synthesis of Selected Schiff Base Derivatives of 2,6-Diisopropylbenzenamine}

Compounds $\mathbf{2 a}, \mathbf{2 c}, \mathbf{2 e}$ or $\mathbf{2 f}(2.0 \mathrm{mmol})$ and 2,6-diisopropylaniline $(0.5 \mathrm{~g} ; 0.565 \mathrm{~mL} ; 3.0 \mathrm{mmol})$ were dissolved in dry chloroform $(70 \mathrm{~mL})$ and then the resulting reaction mixture was brought to a gentle reflux for $40 \mathrm{~h}$. The reaction mixture was connected with a Soxhlet apparatus in which $\mathrm{MgSO}_{4}$ were placed as dehydrating agent. Next the solvent was evaporated under reduced pressure and the obtained red residue was purified by chromatography and crystallization from acetonitrile to yield precipitates as follows:

5-[(E)-\{[2,6-Di(propan-2-yl)phenyl]imino\}methyl]quinolin-8-ol (3a) orange $0.5 \mathrm{~g}$ (1.4 mmol, 71.1\%); m.p. $=126.1-126.9{ }^{\circ} \mathrm{C} ;{ }^{1} \mathrm{H}-\mathrm{NMR}\left(\mathrm{CDCl}_{3} ; 400.2 \mathrm{MHz}\right) \delta=1.20\left(\mathrm{~d},{ }^{3} J_{\mathrm{H}, \mathrm{H}}=6.9 \mathrm{~Hz}, 12 \mathrm{H}, 4 \mathrm{CH}_{3}\right)$, 3.06 (hept, $\left.{ }^{3} J_{\mathrm{H}, \mathrm{H}}=6.9 \mathrm{~Hz}, 2 \mathrm{H}, 2 \mathrm{CH}\right), 7.10-7.24\left(\mathrm{~m}, 3 \mathrm{H}\right.$, aromatic), $7.35\left(\mathrm{~d},{ }^{3} J_{\mathrm{H}, \mathrm{H}}=8.0 \mathrm{~Hz}, 1 \mathrm{H}\right.$, aromatic), $7.66\left(\mathrm{dd},{ }^{3} J_{\mathrm{H}, \mathrm{H}}=8.7 \mathrm{~Hz},{ }^{4} J_{\mathrm{H}, \mathrm{H}}=4.3 \mathrm{~Hz}, 1 \mathrm{H}\right.$, aromatic), $7.84\left(\mathrm{~d},{ }^{3} J_{\mathrm{H}, \mathrm{H}}=8.0 \mathrm{~Hz}, 1 \mathrm{H}\right.$, aromatic), $8.51(\mathrm{~s}, 1 \mathrm{H}, \mathrm{HC}=\mathrm{N}), 8.91\left(\mathrm{dd},{ }^{3} J_{\mathrm{H}, \mathrm{H}}=4.3 \mathrm{~Hz},{ }^{4} J_{\mathrm{H}, \mathrm{H}}=1.5 \mathrm{~Hz}, 1 \mathrm{H}\right.$, aromatic $), 10.04\left(\mathrm{~d},{ }^{3} J_{\mathrm{H}, \mathrm{H}}=8.7 \mathrm{~Hz}\right.$, $1 \mathrm{H}$, aromatic); ${ }^{13} \mathrm{C}\left\{{ }^{1} \mathrm{H}\right\}-\mathrm{NMR}\left(\mathrm{CDCl}_{3} ; 100.6 \mathrm{MHz}\right) \delta=23.7,28.3,109.5,122.7,123.2,123.7,124.2,127.3$, 135.1, 135.6, 137.9, 138.3, 148.1, 149.9, 155.2, 162.7; LCMS-IT-TOF: $m / z$ (rel. int.) $(\mathrm{M}+\mathrm{H})^{+}=333(100 \%)$; HRMS (IT-TOF): $\mathrm{m} / z$ Calcd for $\mathrm{C}_{22} \mathrm{H}_{25} \mathrm{~N}_{2} \mathrm{O}(\mathrm{M}+\mathrm{H})^{+}=333.1961$, Found 333.1965; UV-Vis (methanol; $\lambda[\mathrm{nm}](\log \varepsilon)): 327$ (3.88), $271(3.94), 239$ (4.38), 206 (4.43); IR (KBr): $3381 v_{\mathrm{OH}} ; 2858 v_{\mathrm{CH}} ; 2958 v_{\mathrm{OH}}$; $1613 v_{\mathrm{HC}=\mathrm{N}}$. CCDC 1501807.

5-[(E)-\{[2,6-Di(propan-2-yl)phenyl]imino\}methyl]-N,N,2-trimethylquinolin-6-amine (3b) yellow $0.6 \mathrm{~g}$ $(1.5 \mathrm{mmol}, 74.3 \%)$; m.p. $=130.1-130.5{ }^{\circ} \mathrm{C} ;{ }^{1} \mathrm{H}-\mathrm{NMR}\left(\mathrm{CDCl}_{3} ; 400.2 \mathrm{MHz}\right) \delta=1.20\left(\mathrm{~d},{ }^{3} J_{\mathrm{H}, \mathrm{H}}=6.9 \mathrm{~Hz}\right.$, $\left.12 \mathrm{H}, 4 \mathrm{CH}_{3}\right), 2.77\left(\mathrm{~s}, 3 \mathrm{H}, \mathrm{CH}_{3}\right), 2.90\left(\mathrm{~s}, 6 \mathrm{H}, 2 \mathrm{NCH}_{3}\right), 3.11\left(\mathrm{hept}^{3} J_{\mathrm{H}, \mathrm{H}}=6.9 \mathrm{~Hz}, 2 \mathrm{H}, 2 \mathrm{CH}\right), 7.14\left(\mathrm{dd}^{3}{ }^{3} \mathrm{H}_{\mathrm{H}, \mathrm{H}}\right.$ $=8.6 \mathrm{~Hz},{ }^{3} J_{\mathrm{H}, \mathrm{H}}=6.6 \mathrm{~Hz}, 1 \mathrm{H}$, aromatic), $7.19-7.23(\mathrm{~m}, 2 \mathrm{H}$, aromatic $), 7.38\left(\mathrm{~d},{ }^{3} J_{\mathrm{H}, \mathrm{H}}=8.9 \mathrm{~Hz}, 1 \mathrm{H}\right.$, aromatic), $7.64\left(\mathrm{~d},{ }^{3} J_{\mathrm{H}, \mathrm{H}}=9.2,1 \mathrm{H}\right.$, aromatic), $8.18\left(\mathrm{~d},{ }^{3} J_{\mathrm{H}, \mathrm{H}}=9.2 \mathrm{~Hz}, 1 \mathrm{H}\right.$, aromatic), $8.80(\mathrm{~s}, 1 \mathrm{H}, \mathrm{HC}=\mathrm{N})$, $10.00\left(\mathrm{~d},{ }^{3} J_{\mathrm{H}, \mathrm{H}}=8.9,1 \mathrm{H}\right.$, aromatic); ${ }^{13} \mathrm{C}\left\{{ }^{1} \mathrm{H}\right\}-\mathrm{NMR}\left(\mathrm{CDCl}_{3} ; 100.6 \mathrm{MHz}\right) \delta=23.9,24.7,28.1,46.2,121.3$, 122.7, 123.3, 123.7, 124.2, 126.1, 132.5, 135.4, 137.9, 144.1, 150.17, 155.1, 157.1, 162.5; LCMS-IT-TOF: $\mathrm{m} / \mathrm{z}$ 
(rel. int.) $(\mathrm{M}+\mathrm{H})^{+}=374(100 \%)$; HRMS (IT-TOF): $m / z$ Calcd for $\mathrm{C}_{25} \mathrm{H}_{32} \mathrm{~N}_{3}(\mathrm{M}+\mathrm{H})^{+}=374.2590$, Found 374.2588; UV-Vis (methanol; $\lambda$ [nm] (loge)): 377 (3.87), 306 (4.06), 260 (4.59), 214 (4.71); IR (KBr): $2959 v_{\mathrm{CH}} ; 1629 v_{\mathrm{HC}=\mathrm{N}}$. CCDC 1501808.

5-[(E)-\{[2,6-Di(propan-2-yl)phenyl]imino\}methyl]-N,N-dimethylquinolin-6-amine (3c) dark yellow $0.6 \mathrm{~g}$ (1.6 mmol, 80.3\%); m.p. $=116.9-117.2{ }^{\circ} \mathrm{C} ;{ }^{1} \mathrm{H}-\mathrm{NMR}\left(\mathrm{CDCl}_{3} ; 400.2 \mathrm{MHz}\right) \delta=1.25\left(\mathrm{~d},{ }^{3} J_{\mathrm{H}, \mathrm{H}}=6.9 \mathrm{~Hz}\right.$, $\left.12 \mathrm{H}, 4 \mathrm{CH}_{3}\right), 2.97\left(\mathrm{~s}, 6 \mathrm{H}, 2 \mathrm{NCH}_{3}\right), 3.14$ (hept, $\left.{ }^{3} \mathrm{~J}_{\mathrm{H}, \mathrm{H}}=6.9 \mathrm{~Hz}, 2 \mathrm{H}, 2 \mathrm{CH}\right), 7.16-7.32(\mathrm{~m}, 3 \mathrm{H}$, aromatic), $7.53\left(\mathrm{dd}^{3} \mathrm{~J}_{\mathrm{H}, \mathrm{H}}=8.8 \mathrm{~Hz},{ }^{4} J_{\mathrm{H}, \mathrm{H}}=4.1 \mathrm{~Hz}, 1 \mathrm{H}\right.$, aromatic $), 7.72\left(\mathrm{~d},{ }^{3} J_{\mathrm{H}, \mathrm{H}}=9.2 \mathrm{~Hz}, 1 \mathrm{H}\right.$, aromatic $), 8.27\left(\mathrm{~d},{ }^{3} J_{\mathrm{H}, \mathrm{H}}\right.$ $=9.2 \mathrm{~Hz}, 1 \mathrm{H}$, aromatic), $8.84(\mathrm{~s}, 1 \mathrm{H}, \mathrm{HC}=\mathrm{N}), 8.89\left(\mathrm{dd},{ }^{3} J_{\mathrm{H}, \mathrm{H}}=4.0 \mathrm{~Hz},{ }^{4} J_{\mathrm{H}, \mathrm{H}}=1.4 \mathrm{~Hz}, 1 \mathrm{H}\right.$, aromatic), $10.15\left(\mathrm{~d},{ }^{3} \mathrm{~J}_{\mathrm{H}, \mathrm{H}}=8.7 \mathrm{~Hz}, 1 \mathrm{H}\right.$, aromatic $) ;{ }^{13} \mathrm{C}\left\{{ }^{1} \mathrm{H}\right\}-\mathrm{NMR}\left(\mathrm{CDCl}_{3} ; 100.6 \mathrm{MHz}\right) \delta=23.9,28.1,46.2,120.8$, 122.6, 122.7, 123.2, 124.2, 128.0, 133.5, 134.9, 137.9, 144.8, 148.4, 150.1, 155.7, 162.3; LCMS-IT-TOF: $m / z$ (rel. int.) $(\mathrm{M}+\mathrm{H})^{+}=360(100 \%)$; HRMS (IT-TOF): $m / z$ Calcd for $\mathrm{C}_{24} \mathrm{H}_{30} \mathrm{~N}_{3}(\mathrm{M}+\mathrm{H})^{+}=360.2434$, Found 360.2432; UV-Vis (methanol; $\lambda$ [nm] (loge)): 379 (3.62), 305 (3.80), 263 (4.29), 213 (4.42); IR (KBr): $2959 v_{\mathrm{CH}} ; 1619 v_{\mathrm{HC}=\mathrm{N}}$. CCDC 1829344.

(E)-7-(((2,6-Diisopropylphenyl)imino)methyl)-5-methylquinolin-8-ol (3d) yellow $0.5 \mathrm{~g}(1.6 \mathrm{mmol}, 78.0 \%)$; m.p. $=175.1-176.1{ }^{\circ} \mathrm{C} ;{ }^{1} \mathrm{H}-\mathrm{NMR}\left(\mathrm{CDCl}_{3} ; 500.18 \mathrm{MHz}\right) \delta=1.25\left(\mathrm{~d},{ }^{3} \mathrm{~J}_{\mathrm{H}, \mathrm{H}}=6.9 \mathrm{~Hz}, 12 \mathrm{H}, 4 \mathrm{CH}_{3}\right)$, $2.63\left(\mathrm{~d},{ }^{4} J_{\mathrm{H}, \mathrm{H}}=0.9 \mathrm{~Hz}, 3 \mathrm{H}, \mathrm{CH}_{3}\right), 3.09$ (hept, $\left.{ }^{3} J_{\mathrm{H}, \mathrm{H}}=6.8 \mathrm{~Hz}, 2 \mathrm{H}, 2 \mathrm{CH}\right), 7.23-7.24(\mathrm{~m}, 4 \mathrm{H}$, aromatic), $7.58\left(\mathrm{dd},{ }^{3} J_{\mathrm{H}, \mathrm{H}}=8.5 \mathrm{~Hz},{ }^{4} J_{\mathrm{H}, \mathrm{H}}=4.2 \mathrm{~Hz}, 1 \mathrm{H}\right.$, aromatic), $8.28\left(\mathrm{dd},{ }^{3} J_{\mathrm{H}, \mathrm{H}}=8.5 \mathrm{~Hz},{ }^{4} J_{\mathrm{H}, \mathrm{H}}=1.6 \mathrm{~Hz}, 1 \mathrm{H}\right.$, aromatic), $8.38(\mathrm{~s}, 1 \mathrm{H}, \mathrm{HC}=\mathrm{N}), 9.03\left(\mathrm{dd},{ }^{3} J_{\mathrm{H}, \mathrm{H}}=4.2 \mathrm{~Hz},{ }^{4} J_{\mathrm{H}, \mathrm{H}}=1.6 \mathrm{~Hz}, 1 \mathrm{H}\right.$, aromatic), $14.46(\mathrm{~s}, 1 \mathrm{H}$, $\mathrm{OH}) ;{ }^{13} \mathrm{C}\left\{{ }^{1} \mathrm{H}\right\}-\mathrm{NMR}\left(\mathrm{CDCl}_{3} ; 125.78 \mathrm{MHz}\right) \delta=18.1,23.7,28.3,113.9,123.1,123.3,123.5,126.1,127.5$, 130.9, 132.5, 139.7, 141.3, 144.5, 149.1, 161.2, 165.3; LCMS-IT-TOF: $m / z$ (rel. int.) $(\mathrm{M} \mathrm{-} \mathrm{H})^{-}=345(100 \%)$; HRMS (IT-TOF): $m / z$ Calcd for $\mathrm{C}_{23} \mathrm{H}_{25} \mathrm{~N}_{2} \mathrm{O}(\mathrm{M}-\mathrm{H})^{-}=345.1967$, Found 345.1969; UV-Vis (methanol; $\lambda$ [nm] (loge)): 446 (2.98), 361 (3.17), 277 (3.93), 226 (3.71), 208 (4.02); IR (KBr): $3062 v_{\mathrm{OH}} ; 2962 v_{\mathrm{CH}}$; $1617 v_{\mathrm{HC}=\mathrm{N}}$. CCDC 1829345.

\subsection{Crystallization}

Crystals suitable for $\mathrm{X}$-ray analysis were obtained from a hot acetonitrile solution for $\mathbf{3 a}, \mathbf{3 b}, \mathbf{3 c}$ and $\mathbf{3 d}$, and from a hot $\mathrm{CHCl}_{3}$ solution for $\mathbf{2 h}$.

\section{Conclusions}

The research has been focused on the synthesis of quinolinecarbaldehydes $\mathbf{2}$ and Schiff bases $\mathbf{3}$ as their derivatives. The presented synthesis protocols allowed the synthesis of the target compounds more efficiently with yields up to $75 \%$ for molecule $2 \mathrm{c}$ and $80.3 \%$ for compound $3 \mathrm{c}$. The structures of the obtained molecules were proved by a combination of various techniques, such as NMR, IR, GC-MS, MS, HRMS, UV-Vis and X-ray crystallography. The chemistry was mostly based on inexpensive and commercially available reagents. A variety of substituents (halogens $\mathrm{Cl}$ and $\mathrm{Br}$ and hydroxyl, methyl and $\mathrm{NMe}_{2}$ groups) were chosen in order to represent different electronic features. Formylation reactions of electron-rich aromatics in our studies mainly led to quinoline-5-carbaldehyde structures with newly formed carbonyl groups at the $C 5$ position. In the case of a $C 5$ position blocked by bromine or chlorine atoms or methyl groups, formylation reactions produced quinoline-7-carbaldehydes with the carbonyl group in C7 position. We presented a very simple, chromatography-free procedure for the double formylation of 2-methylquinolin-8-ol and benzo[h]quinolin-10-ol using very convenient Duff reaction protocols. For the first time we showed a carbene insertion reaction into C-Br bonds to produce 7-bromo-8-hydroxyquinoline-5-carbaldehyde by applying the Reimer-Tiemann method. The electrochemical properties of compounds $\mathbf{2} \mathbf{a}, \mathbf{2} \mathbf{e}$ and $\mathbf{2} \mathbf{f}$ were investigated. Oxidation and reduction potentials of these compounds in acetonitrile showed the influence of the various functional groups in the structure.

Supplementary Materials: The following are available online, CCDC 1890715, 1501807, 1501808, 1829344 and 1829345 for $\mathbf{2 h}, \mathbf{3 a}, \mathbf{3 b}, \mathbf{3 c}$ and $\mathbf{3 d}$, respectively contains the supplementary crystallographic data for the compounds. These data can be obtained free of charge from http://www.ccdc.cam.ac.uk/conts/retrieving.html, or from the 
Cambridge Crystallographic Data Centre, 12 Union Road, Cambridge CB2 1EZ, UK; fax: (+44) 1223-336-033; or e-mail: deposit@ccdc.cam.ac.uk. Calculations have been carried out in Wroclaw Centre for Networking and Supercomputing (http://www.wcss.wroc.pl).

Author Contributions: J.W., M.S., J.E.N. performed the experiments; M.K. and J.K. X-ray measurements and diffraction data analysis; A.Q. and J.W. performed the electrochemical experiments; R.S. and S.G. electrochemistry data analysis; J.W. and R.S. theoretical calculations (DFT); M.S. and J.W. IR and UV-Vis measurements; J.E.N. designed and analyzed the data; J.E.N., J.W. and R.S. wrote and edited manuscript. All authors have read and agreed to the published version of the manuscript.

Funding: Romana Sokolova greatly acknowledges the Czech Academy of Sciences (RVO:61388955).

Acknowledgments: We thank the Erasmus Plus for the 3 months award to stay at J. Heyrovský Institute of Physical Chemistry of the Czech Academy of Sciences, Dolejskova 3, 18223, Prague, Czech Republic to J. Wantulok.

Conflicts of Interest: The authors declare no conflict of interest.

\section{References}

1. Wynberg, H. The Reimer-Tiemann reaction. Chem. Rev. 1960, 169-184. [CrossRef]

2. González-Vera, J.A.; Luković, E.; Imperiali, B. Synthesis of Red-Shifted 8-Hydroxyquinoline Derivatives Using Click Chemistry and Their Incorporation into Phosphorylation Chemosensors. J. Org. Chem. 2009, 74, 7309-7314. [CrossRef] [PubMed]

3. Chen, Y.; Wang, H.; Wan, L.; Bian, Y.; Jiang, J. 8-Hydroxyquinoline-Substituted Boron-Dipyrromethene Compounds: Synthesis, Structure, and OFF-ON-OFF Type of pH-Sensing Properties. J. Org. Chem. 2011, 76, 3774-3781. [CrossRef]

4. Ding, X.; Zhang, F.; Bai, Y.; Zhao, J.; Chen, X.; Ge, M.; Sun, W. Quinoline-based highly selective and sensitive fluorescent probe specific for $\mathrm{Cd}^{2+}$ detection in mixed aqueous media. Tetrahedron Lett. 2017, 58, 3868-3874. [CrossRef]

5. Nycz, J.E.; Malecki, G.J. Synthesis, spectroscopy and computational studies of selected hydroxyquinoline carboxylic acids and their selected fluoro-, thio-, and dithioanalogues. J. Mol. Struct. 2013, 1032, 159-168. [CrossRef]

6. Szala, M.; Nycz, J.E.; Malecki, G.; Sokolova, R.; Ramesova, S.; Switlicka-Olszewska, A.; Strzelczyk, R.; Podsiadly, R.; Machura, B. Synthesis of 5-azo-8-hydroxy-2-methylquinoline dyes and relevant spectroscopic, electrochemical and computational studies. Dyes Pigm. 2017, 142, 277-292. [CrossRef]

7. Ogata, Y.; Kawasaki, A.; Suguria, F. Kinetics and mechanism of the Duff reaction. Tetrahedron 1968, 24, 5001-5010. [CrossRef]

8. Lu, Z.-N.; Wang, L.; Zhang, X.; Zhu, Z.-J. A selective fluorescent chemosensor for $\mathrm{Cd}^{2+}$ based on 8-hydroxylquinoline-benzothiazole conjugate and imaging application. Spectrochim. Acta A 2019, 213, 57-63. [CrossRef]

9. Mahajan, S.S.; Scian, M.; Sripathy, S.; Posakony, J.; Lao, U.; Loe, T.K.; Leko, V.; Thalhofer, A.; Schuler, A.D.; Bedalov, A.; et al. Development of Pyrazolone and Isoxazol-5-one Cambinol Analogues as Sirtuin Inhibitors. J. Med. Chem. 2014, 57, 3283-3294. [CrossRef]

10. Olah, G.A. Mechanism of Electrophilic Aromatic Substitutions1. Accounts Chem. Res. 1971, 4, $240-248$. [CrossRef]

11. DeAngelis, F.; Inesi, A.; Feroci, M.; Nicoletti, R. Reaction of electrogenerated dichlorocarbene with methylindoles. J. Org. Chem. 1995, 60, 445-447. [CrossRef]

12. Nandhakumar, R.; Suresh, T.; Calistus Jude, A.L.; Kannan, V.R.; Mohan, P.S. Synthesis, antimicrobial activities and cytogenetic studies of newer diazepino quinoline derivatives via Vilsmeier-Haack reaction. Eur. J. Med. Chem. 2007, 42, 1128-1136. [CrossRef] [PubMed]

13. Bollyn, M. Thermal Hazards of the Vilsmeier-Haack Reaction on N,N-Dimethylaniline. Org. Process Res. Dev. 2005, 9, 982-996. [CrossRef]

14. Hitchcock, P.B.; Lappert, M.F.; Nycz, J.E. Synthesis, structure and reductive dechlorination of the C-centred phosphorus(III) b-diketiminate PCl(Ph)L [L = C\{C(Me)NC6H3Pr2i-2,6\}\{C(Me)NHC(6)H(3)Pr(i)2-2,6\}]. Chem. Commun. 2003, 10, 1142-1143. [CrossRef] [PubMed]

15. Sheldrick, G.M. Crystal structure refinement with SHELXL. Acta Cryst. 2015, C71, 3-8.

16. Lund, H.; Hammerich, O. Organic Electrochemistry, 4th ed.; Marcel Dekker, Inc.: New York, NY, USA, 2001. 
17. Sokolova, R.; Hromadova, M.; Ludvik, J.; Pospisil, L.; Giannarelli, S. The Autoprotonation in Reduction Mechanism of Pesticide Ioxynil. Electrochim. Acta 2010, 55, 8336-8340. [CrossRef]

18. Sokolova, R.; Gal, M.; Valasek, M. New Proton Donors in Electrochemical Mechanistic Studies in Non-Aqueous Solution Dimethylsulfoxide: Chlorinated Hydroxybenzonitriles. J. Electroanal. Chem. 2012, 685, 33-36. [CrossRef]

19. Smith, P.J.; Mann, C.K. Electrochemical dealkylation of aliphatic amines. J. Org. Chem. 1969, 34, $1821-1826$. [CrossRef]

20. Nycz, J.E.; Szala, M.; Malecki, G.J.; Nowak, M.; Kusz, J. Synthesis, spectroscopy and computational studies of selected hydroxyquinolines and their analogues. Spectrochim Acta A 2014, 117, 351-359. [CrossRef]

21. Petit, M.; Tran, C.; Roger, T.; Gallavardin, T.; Dhimane, H.; Palma-Cerda, F.; Blanchard-Desce, M.; Acher, F.C.; Ogden, D.; Dalko, P.I. Substitution Effect on the One- and Two-photon Sensitivity of DMAQ "Caging" Groups. Org. Lett. 2012, 14, 6366-6369. [CrossRef]

22. Wang, D.; Kuang, D.; Zhang, F.; Yang, C.; Zhu, X. Room-Temperature Copper-Catalyzed Arylation of Dimethylamine and Methylamine in Neat Water. Adv. Synth. Catal. 2015, 357, 714-718. [CrossRef]

23. Whiteoak, C.J.; Planas, O.; Company, A.; Ribas, X. A First Example of Cobalt-Catalyzed Remote C-H Functionalization of 8-Aminoquinolines Operating through a Single Electron Transfer Mechanism. Adv. Synth. Catal. 2016, 358, 1679-1688. [CrossRef]

24. Gassiorowska, M.; Typek, J.; Soroka, J.A.; Sawicka, M.J.; Wróblewska, E.K.; Guskos, N.; Żołnierkiewicz, G. Spectroscopic and magnetic properties of solvatochromic complex of $\mathrm{Cu}^{2+}$ and novel $3 \mathrm{H}$-indolium derivative. Spectrochim. Acta A 2014, 124, 300-307. [CrossRef] [PubMed]

25. Fiedler, H. Synthesis of methyl-8-hydroxyquinoline aldehydes. Arch. Pharm. 1960, 293, 609-621. [CrossRef] [PubMed]

26. Voloshin, N.A.; Chernyshev, A.V.; Bezuglyi, S.O.; Metelitsa, A.V.; Voloshina, E.N.; Minkin, V.I. Spiropyrans and spirooxazines 4 . Synthesis and spectral properties of 6 '-halo-substituted spiro[indoline-2,2'-2H-pyrano [3,2-h]quinolines]. Russ. Chem. Bull. Int. Ed. 2008, 57, 151-158. [CrossRef]

27. Skonieczny, K.; Charalambidis, G.; Tasior, M.; Krzeszewski, M.; Kalkan-Burat, A.; Coutsolelos, A.G.; Gryko, D.T. General and Efficient Protocol for Formylation of Aromatic and Heterocyclic Phenols. Synthesis-Stuttgart 2012, 44, 3683-3687.

28. Hansen, P.E.; Kamounah, F.S.; Gryko, D.T. Deuterium Isotope Effects on C-13-NMR Chemical Shifts of 10-Hydroxybenzo[h]quinolines. Molecules 2013, 18, 4544-4560. [CrossRef]

29. Bobranski, B. The oxy-6-quinolin-aldehyde-5 and several resultant represented 5,6-substituted quinoline derivatives. J. Prakt. Chem. 1932, 134, 141-152.

30. Kisin-Finfer, E.; Redy-Keisar, O.; Roth, M.; Ben-Eliyahu, R.; Shabat, D. Molecular Insight into Long-Wavelength Fluorogenic Dye Design: Hydrogen Bond Induces Activation of a Dormant Acceptor. Chem. Eur. J. 2015, 21, 18566-18570. [CrossRef]

31. Morimura, S.; Horiuchi, H.; Murayama, K. Vilsmeier Reaction of Phenols. I. Synthesis of Aryl Formates. Bull. Chem. Soc. Jpn. 1977, 8, 2189-2190. [CrossRef]

Sample Availability: Samples of the compounds $\mathbf{2 e}, \mathbf{2 f}, \mathbf{2 \mathbf { j }}, \mathbf{2 h}, \mathbf{2 k}, \mathbf{3 a}, \mathbf{3 b}, \mathbf{3 c}, \mathbf{3 d}$ are available from the authors.

(C) 2020 by the authors. Licensee MDPI, Basel, Switzerland. This article is an open access article distributed under the terms and conditions of the Creative Commons Attribution (CC BY) license (http://creativecommons.org/licenses/by/4.0/). 